\title{
ÉPÍTÉSZET ÉS SAJTÓ - A HISTORIZMUS ÖT JELENTŐS SZAKRÁLIS ÉPÍTÉSZETI PÁLYÁZATA ${ }^{1}$
}

\author{
NÉMETH NÓRA*四 - MARÓTZY KATALIN** \\ *PhD-hallgató. BME Építészettörténeti és Mủemléki Tanszék, 1111 Budapest, Mủegyetem rkp. 3. K II. 82. \\ E-mail: nemeth.nora@edu.bme.hu \\ **PhD, egyetemi adjunktus. BME Építészettörténeti és Mủemléki Tanszék, \\ 1111 Budapest, Müegyetem rkp. 3. K II. 82. Tel.: (+36-1) 463-1330. E-mail: mkata@et.bme.hu
}

\begin{abstract}
A historizmus építészeti pályázatainak témakörében különös figyelmet érdemel ezek korabeli megjelenése. A tervversenyeinek anyagát elsősorban a szaksajtóból ismerjük, ritkábban építészhagyatékok anyagából tárhatók fel. A sajtóban értelemszerủen a háromdimenziós építészet jellemző prezentációja máig kétdimenziós formában képekkel, tervekkel és a hozzájuk különböző módon kapcsolódó szövegekkel történik. A szöveg és illusztráció kapcsolatát, annak változását itt öt példán keresztül mutatjuk be. Választott esettanulmányaink - Kaposvár, római katolikus templom átépítése 1883-84; Budapest, Fazekas téri református templom 1891-92; Budapest, Lipótvárosi zsinagóga 1898-99; Szeged, Fogadalmi templom 1903-04; Budapest, Ferenc József jubileumi templom 1913-14 - mind szakrális épületek, melyek építése a helyi közösség számára különös jelentőséggel bírt, így nemcsak az építészeti folyóiratokban, hanem a napi- és családi lapokban is böséggel megjelenő témát szolgáltattak, ami lehetőséget ad arra, hogy az építészeti tervek bemutatásának tágabb kontextusát is vizsgáljuk.
\end{abstract}

Kulcsszavak: historizmus, századforduló, tervpályázat, építészeti pályázat, építészettörténet

\section{BEVEZETÉS}

A historizmus pályázatainak vizsgálatakor ${ }^{2}$ elsődleges forrásunk a korabeli szaksajtó, ami egyre bővülő képanyaggal számolt be a tervversenyekröl. Az alapvető történeti és építészeti információk keresésén túl is érdemes forgatni az Épitési Ipart, a Magyar Mérnök- és Épitészegylet Közlönyét, a Magyar Pályázatokat, az Épitészeti Szemlét és a Bauzeitungot; a szövegek és illusztrációk további érdekes aspektusokat vethetnek fel. A szaksajtó keretein belül érdekes Bécs felé is tekintenünk, mely jelentősebb magyar pályázatok milyen kontextusban jelentek meg a Monarchia központjának szakfolyóirataiban. A bírálati jegyzőkönyvek és pályázati beszámolók szerkesztésükben, szövegezésükben betekintést engednek az építészi gondolkodás és értékelés folyamatába, amit az illusztrációk egyidejü vizsgálata a kép-szöveg viszonyon keresztül kiegészít. ${ }^{3}$ Az építészet recepciójának másik, eltérő szemléletủ oldala a nagyközönségé. Természetesen itt más a befogadó közeg képzettsége és érdeklödése. A laikus és szakértő szerzők pályázatokat taglaló cikkei a családi és napilapok-

\footnotetext{
${ }^{凶}$ Levelező szerző.

${ }^{1}$ A tanulmány a Bolyai János Kutatási Ösztöndíj támogatásával készült.

${ }^{2}$ A historizmus pályázatai világának általános tendenciáiról: Székely-Marótzy 2018.

${ }^{3}$ A szaksajtó ilyen szempontú vizsgálata: Németh-Marótzy 2019.
} 
ban ugyan kevésbé voltak rendszeresek, de egy-egy nagyobb beruházás kapcsán igyekeztek beszámolni a közérdeklődésre számot tartó eseményekről, amilyenek a templomépítések is voltak.

A 19. század második felétől az I. világháborúig a szakrális épületek tervezése ${ }^{4}$ - a mennyiséget tekintve - kevésbé volt meghatározó építészeti feladat a korábbi időszakokhoz képest. A török háborúk utáni újjáépítés - mely elsősorban a katolikus plébániákat érintette -, a II. József-féle türelmi rendelet ${ }^{5}$ utáni evangélikus ${ }^{6}$ és református $^{7}$ templomépítési konjunktúra a historizmus időszakára már lecsengett. Így korszakunkban a zsinagógákon ${ }^{8}$ kívül elsősorban azokon a területeken volt szükség új templomra, ahol a kapitalizálódó fejlődés jelentős népességnövekedéssel járt. E tendenciák a pályázatok számában és eloszlásában is nyomon követhetőek; a korszak másfél ezernyi magyar pályázatának csak egytizede szólt szakrális épületek tervezésére, köztük is csak elenyésző számban római katolikus templomra. Jelentősen több versenyt írtak ki a reformált egyházak és természetesen igen sokat az izraelita hitközségek. A század utolsó negyedétől pedig egyre gyakoribbá váltak a felújítások és restaurálások. ${ }^{9}$

Noha számosságában a templomtervezés kisebb részét tette ki az építészeti gyakorlatnak, a szakrális építészet tervezéselméletével foglalkozó munkák szaporodása ${ }^{10}$ jelzi, hogy a téma fontosságából nem vesztett. Ráadásul a templomépítés még ekkor is az egyes közösségek életében meghatározó, identitásukkal szoros összefüggésben álló esemény volt. ${ }^{11}$ Így egy-egy szakrális épület tervezésére kiírt pályázat különös érdeklődésre tarthatott számot, sajtómegjelenésük is bőséges. Az alábbi öt példán keresztül - Kaposvár, római katolikus templom átépítése 1883-84; Budapest, Fazekas téri református templom 1891-92; Budapest, Lipótvárosi zsinagóga 1898-99; Szeged, Fogadalmi templom 1903-04; Budapest, Ferenc József jubileumi templom 1913-14 - elsődlegesen azt vizsgáljuk, hogy az építészeti gondolatok miként jelentek meg a sajtóban; a bírálatok, tárcák, hírek és elemzések hogyan közvetítik a terveken vizuálisan megjelenő tartalmakat, milyen a szöveg és az illusztráció kapcsolata.

\section{KAPOSVÁR, RÓMAI KATOLIKUS TEMPLOM ÁTÉPÍTÉSE 1883-1884}

Első példánk a Somogy megyei Kaposvár római katolikus templomának román stílusú kibővítésére kiírt pályázat, mellyel egy olyan esetet mutatunk be, amikor a tervek szöveges bemutatását nem kísérte ábraanyag a sajtóban. A városi rangot 1873-

${ }^{4}$ A tendenciákról bővebben: Sisa 2013. 378-414.

${ }^{5} 1781$. október 25 .

${ }^{6}$ Winkler 1992. XXXI; Krähling 2004. 17.

${ }^{7}$ Takács 1992. XIX.

${ }^{8}$ Klein 2011. 82. Az izraelita vallás csak 1867-ben került a bevett vallások közé (1867. évi XVII. törvénycikk az izraeliták egyenjogúságáról polgári és politikai jogok tekintetében).

${ }^{9} \mathrm{~A}$ szerzők által készített adatbázis alapján, mely a magyar szaksajtó adatait dolgozza fel.

${ }^{10} \mathrm{Az}$ elmélet és gyakorlat kapcsolatáról részletesen: Krähling 2014; Krähling 2015; Krähling 2017.

${ }^{11}$ Németh-Marótzy 2018. 
ban ${ }^{12}$ elnyerő település lakossága a 19. század második felében megháromszorozódott, plébániatemplomának bővítése elkerülhetetlenné vált. Az első elképzeléseket egy helyi mester, Heindlhoffer Antal készítette, a város azonban nagyszabású megoldást keresett, és építészeti pályázatot írtak ki. ${ }^{13}$ Ennek részleteiröl 1883. július 14-én határozott a templomépítő bizottság, a titkos-jeligés pályázat kiírása az Épitési Iparban 1883. július 29-én jelent meg. Ez formájában inkább egy féloldalas hirdetés volt, a lapnak volt pályázati rovata is, de nem ott tették közzé a felhívást. ${ }^{14} \mathrm{~A}$ tervek kidolgozására nagyjából fél év állt rendelkezésre, ami nem számított sem kiugróan kevésnek, sem különösebben hosszúnak a korszakban. A költségvetési összeg és a zsűri is szerepelt a kiírásban, ugyan nem személy szerint említve a tagokat, de a Magyar Mérnök- és Építész-Egyletet mint delegáló szervezetet megjelölve. A pályázati eljárást nem is érte szakmai kritika, feltehetően azért, mert a város előre egyeztetett az Egylettel. Az Épitési Iparban pontosan beszámoltak a részletekről: a pályamüvek beérkezése után a december 17-i Mü- és középítési szakosztály ülésén felkérték a bírálókat. A bírálóbizottsági jelentés 1884. január 21-én készült el. ${ }^{15}$ A kaposvári templomépítő bizottság elégedett volt a bírálók munkájával, még hálás köszönőlevelet is írtak, minden bizonnyal amiatt is, mert az Egylet tagjai fizetség nélkül vállalták a feladatot.

1884-ben az építészeti sajtó már túl volt az első lépések nehézségein, a szakírók már kialakult közönségkörnek írtak a rendszeresen megjelenő orgánumokban - a Magyar Mérnök- és Épitész Egylet Közlönyében és Heti Értesitoójében, az Épitési Iparban és a Bauzeitung für Ungarnban. ${ }^{16}$ Példánk azt illusztrálja, hogy egy pályázat milyen típusú publicitást kapott ekkoriban: szöveges magyarázatot közöltek, ábraanyaggal ellátott cikkeket nem, vagy rendkívül ritkán. Ez azért is érdekes, mert a nyertes építészek mind budapestiek voltak, ${ }^{17}$ akárcsak az Egylet tagságának többsége, és az építészeti lapok szerkesztőségei; így nem a távolság vagy az információ hiánya miatt nem jelentek meg a tervek. A nyomdatechnika fejlödése és a nagy mennyiségü képközlés megfizethető elérhetősége még váratott magára.

A szűk körü, személyes ismeretségekkel átszőtt pályázati helyzet később sok kritika alapja lett, de 1884-ben még csak annyit látni, hogy a legtöbb építészeti pályázat az építészek magánügye maradt. A bírálatot a korszak legjelentősebb építészei készítették; Ybl Miklós a szakma doyenje, ${ }^{18}$ Steindl Imre és Czigler Győző egyetemi

${ }^{12}$ Budapesti Közlöny 6 (1872) szeptember 27.

${ }^{13} \mathrm{Az}$ előzményekröl és az építés történetéről részletesen: Hoss 1948; Dercsényi 1999.

${ }^{14}$ Pályázati hirdetés, ÉPIP 7 (1883) 288.

${ }^{15}$ Czigler-Steindl-Ybl 1884.

${ }^{16}$ A Magyar Mérnök- és Épitészegylet Közlönye 1867-től, Heti Értesitője 1882-től, az Épitési Ipar (később Építő Ipar) 1877-től, a Bauzeitung für Ungarn - előzményeit is számítva - 1872-től jelent meg.

${ }^{17}$ Valószínüleg majdnem az összes pályázó jelen volt azon az ülésen, ahol az eredményt kihirdették, az erről szóló jelentésben meg is említik, hogy az díjazottokat megéljenezték a tagtársak. (Mü- és középítési szakosztály január 21-i ülése. ÉPIP 8 [1884] 34.)

${ }^{18} \mathrm{~A}$ kor legsikeresebb építésze nem csak számtalan pályázati zsűriben vett részt bírálóként, saját vagyonából finanszírozta az Egylet közlönyének első négy számát, a fiatal építészek számára kiírt belső pályázatok díjazását is többször vállalta. Így noha maga nem volt az ilyen versenyek rendszeres tervezö-résztvevője, a pályázati élet fejlődését, az eljárás terjedését tevőlegesen is támogatta (Majorossy 1930. 58; Marótzy 2014). 
tanárok. A három tag teljes mértékben megfelelt a templomépítő bizottság elképzeléseinek, akik azzal kérték fel az Egyletet a zsüri feladatainak ellátására, hogy a praktikus szempontok mellett az egyházi müépítészet igényeinek is leginkább megfelelö tervet válasszák ki Kaposvár számára. ${ }^{19}$

Az Épitési Iparban egy az egyben közölt jelentés elején ismertetik, hogy alapos vizsgálatot tartottak, bár ennek eredménye pályamüvenként csak pár sor értékelés. A beérkezés sorrendjében haladtak, száraz adatokkal kezdték (tervlapok száma, költségvetés), vizsgálták, hogy a müvek megfelelnek-e a pályázati kiírásnak. Az ezután következő leírásokban nincs kötött tartalmi sorrend, de állandó elemekből épül fel a szöveg: a stílus megnevezése, az építész szorgalmának, arányérzékének, képzettségének értékelése.

A két nyertes terv értékelése már voltaképp az eredményhirdetés előtt elárulta, hogy jó helyezést fognak kapni: a hatos számú „Ad majorem dei Gloriam” jeligés terv - Aigner Sándor munkája - a második helyezett lett. A zsüri szerint az építész megtalálta a feladat lényegét és a múvészi kialakítás mellett takarékos is volt. Az értékelés végén kiemelik, hogy a választott stílusban milyen jártas. Nem véletlenül: Aigner a zsüritag Steindl Imréhez hasonlóan Friedrich von Schmidt tanítványa volt, és a bírálat évében került Schulek Frigyes mellé tanársegédnek az egyetemre. Schulek Steindl diáktársa volt Schmidt mellett, később az egyetemen váltotta tanári katedráján, nyilvánvalóan mindhárman hasonló, a középkori formákat előtérbe helyező építészeti hozzáállást képviseltek a historizmusban. Aigner pályája elején fóként neoromán templomokat tervezett, majd inkább gótizált és az úgynevezett átmeneti időszak jegyeit használta, ${ }^{20}$ munkássága végén tért vissza a tiszta romanikához. ${ }^{21}$

Tandor Ottó nyertes terve a „Kaposvár 2.” jeligét kapta, ${ }^{22}$ és a legtöbb tervlappal rendelkezett a pályaművek közül. Következetesen végigvitt stílusát és a meglévő épülethez való jó illeszkedést dicsérték. Tandor szintén nem volt független a zsüritől: ő is Steindl Imre tanítványa volt, csak nem az egyetemen, hanem a magán építőirodájában, 1882-től dolgoztak együtt. Nem sokkal a kaposvári templom pályázata után Tandor az Országháza tervező irodában ${ }^{23}$ már Steindl helyettese lett, mestere halála után az építkezést is ő fejezte be. Önálló alkotó építészi munkája mellett legalább

\footnotetext{
${ }^{19}$ Mü- és középítési szakosztály december 17-i ülése. ÉPIP 7 (1883) 480.

${ }^{20}$ Ebben az ízlésben készült az erzsébetvárosi templom pályázatára készített terve. „a terv román-góth átmeneti stylben tartott tiszta basilikalis elrendezésü templomot mutat, nyugaton egy középsö, magas harangtoronynyal; továbbá a kereszthajó két végéhez a keleti oldalon alkalmazott két lépcsö- toronynyal és végre a magas födélzetek keresztezö helyén egy szentélytornyocskával; a mellékszentélyek mindegyike egy-egy polygonból alakittatott, mely közvetetlenül a kereszthajóhoz csatlakozik és kívül nem jut érvényre." (Schulek 1891.)

${ }^{21}$ Kapitány-Horváth 2011.

${ }^{22}$ A jelige annyiban érdekes, hogy valószínütlen, hogy a „Kaposvár 1.” tervet Tandor nyújtotta volna be, mert a zsűri szerint az kifejezetten kezdetleges volt. A beérkezési sorrendbe szedett értékelés alapján a számozás valószínűleg a zsüri megkülönböztetése volt a két nem túl fantáziadús jeligéjű terv között.

${ }^{23}$ A Parlament épületén dolgozó építészkörről: Kelecsényi-Gyetvainé Balogh 2018.
} 
egyenértékü, ha nem fontosabb müemlékhelyreállítói munkássága, ${ }^{24}$ ahogy több, nagyrészt középkori stílusban alkotó, müemlékekkel is foglalkozó pályatársának. ${ }^{25}$

A stíluson kívül jóformán semmit nem tudunk meg az értékelt tervekrôl a közzétett szövegek alapján. Építészeti megoldásokról csak akkor van szó, ha ki szerették volna emelni a hibákat, mert ezeket gyakorlatiasan, a helyi lehetőségeket is ismerve meg is magyarázták. ${ }^{26}$ Ez az értékelési szemlélet részben annak köszönhető, hogy a zsüri kétharmada tanár volt, és mindhárman gyakorló építészek, nagy müvezetői tapasztalattal. Tehát értékeltek, és nem elemeztek apró részletekbe menően, hiszen elvük szerint nem is ez volt a dolguk: az Egylet megalakulásától kezdve azt szorgalmazta, hogy ötletversenyként fogják fel a tervpályázatokat, ahol az összkép, a jó gondolatok vetélkedhetnek egymással, és nem kész kiviteli terveket vártak - ahogy sokszor a megbízók. A szóhasználat is árulkodó: többször szerepel az összkoncepció, a stílben való jártasság, motívumok összhangja, homlokzat kiképzése, építészeti megoldás, müvészi kompozíció szófordulat. Olyan általános megközelítés lenyomata a szöveg, amelyet a mai napig használunk, és fontos alapját képezik a tervek értékelésének; a szöveg nagyon ismerősen cseng régies megfogalmazása ellenére. A jegyzőkönyv a korszakra jellemző, megállapodott szó- és érvkészletet vonultat fel, amelyet a szakma prominens, mindenképp kánonképző tagjai írtak. A bírálati jegyzőkönyv formája, annak szerkesztetlen megjelenése és szűkszavúsága azzal magyarázható, hogy a pályamüveket az Egylet székházában kiállították. ${ }^{27}$ Esetünkben - és a korszakban igen gyakran - az illusztráció és a szöveg ilyen módon szétvált: külön médiumon keresztül került a szakmai közönség elé. Erre, az 1914-re már megszokott hozzáállásra és gyakorlatra Komor Marcell a következőképpen utalt: ,,Sokszor mondottam, hogy közszemlére kifüggesztett tervekröl részletezö méltatást, vagy pláne leírást közölni kárbaveszett munka. Megérdemlik ezek a pályatervek, hogy végignézzük öket akár többször is. "28

A korabeli képes újságokban nem találunk elemző cikket a kaposvári templom pályázatáról, pedig a templomok kiemelt témának számítottak, különösen a középkori műemlékek. Müvészettörténeti írások is leginkább ebben a témában jelentek meg, a kortárs épületekre kevesebb figyelem irányult. Egy egyházi lapban akadtunk

\footnotetext{
${ }^{24}$ Ennek fontos állomása az ócsai templom, amelyről 1895-ben tanulmányt is írt, a helyreállításnak több tervváltozatát közölve, írásában teoretikus fejtegetés és a történelmi bemutatás nélkül alapvetően a praktikum oldaláról közelítette a kérdést. (Tandor 1895.)

${ }^{25}$ Mint az idősebb Schulek Frigyesnek, vagy a közel egykorú Möller Istvánnak.

${ }^{26}$ Például: „Szerző nagy gonddal és fáradsággal készítő munkálatát; de az arányok és összkonceptió nem eléggé sikerültek. Különösen nagyon kezdetleges, úgyszólván megoldatlan az apsis a szegélyző sekrestyékkel együtt. Szerkezeti szempontból a régi falpilléreknek ily módon való alkalmazása alig lehetséges." Vagy: „Terjedelmére nézve az épület a programm határait messze túlhaladja; különösen tekintve, hogy az építés helyszinén megfelelö anyag nem található, a nyers tégla alkalmazása nagy nehézségekbe ütköznék, a nélkül pedig az összhatás tetemesen csökkenne.” (Czigler-Steindl-Ybl 1884.)

${ }^{27}$ Mü- és középítési szakosztály december 17-i ülése. ÉPIP 6 (1883) 480.

${ }^{28}$ Ezrey 1914.
} 
nyomára a templom tervpályázatának,$^{29}$ de arányait tekintve ebben a cikkben is több szó esik a templom építésének okáról. Ez egyébként a magyar ezredéves államiság, az 1896-os Millennium országos ünnepére való készülés is volt, a méltó környezet kialakítása országszerte. A pályázatra vonatkozó információkat itt, ha nem is magától a megbízótól vagy az építészektől szerezték, de legalább átvették az Épitési Iparban megjelent cikkek információit. Dicsérték a kaposvári templomépítő bizottságot, hogy prominens személyekre bízta a döntést, és annak alá is vetette magát. A szaklapok már nem közvetítettek a megvalósulásról, hogy az eredeti terveket mennyiben kellett módosítania Tandornak, a kész épületről és müvészeti berendezéséről is csak egy egyházi lap tudósított a felszentelés után nyolc évvel, 1894-ben. ${ }^{30}$ Az elkészült épület nagy félköríves nyílásaival a romanika, támpilléreivel, torony- és tetőformájával a gótika világát idézi (1. ábra), mai formáját az 1930-as években végzett felújítás csak részben módosította.

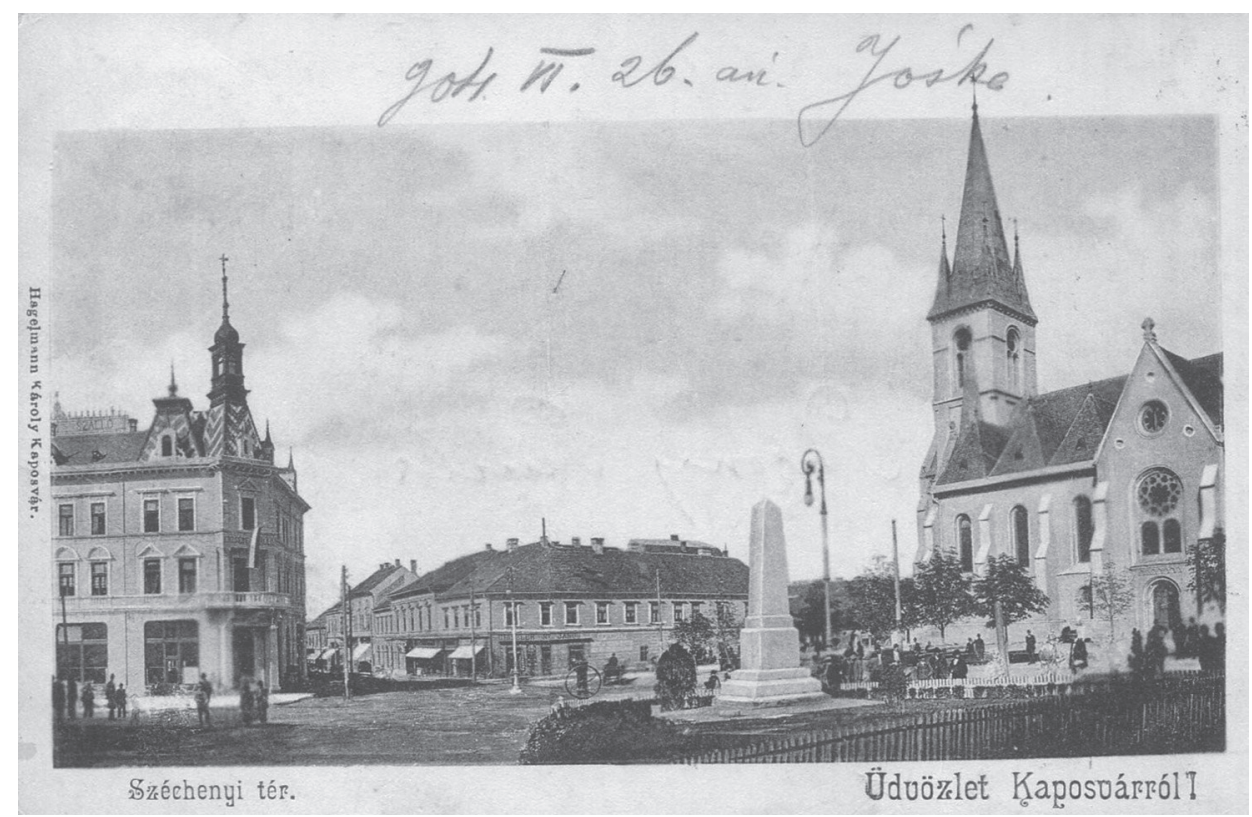

1. ábra. A kaposvári templom a tízes évek elején (régi képeslap)

${ }^{29}$ A kaposvári plébániatemplom ügyében. EL 4 (1884) 52-57.

${ }^{30}$ A Katolikus Szemle című folyóiratnak müvészeti rovata, ahol kiemelték, hogy tiszta román stílusban épült meg a templom. (Velics 1894.) 


\section{BUDAPEST, FAZEKAS TÉRI ${ }^{31}$ REFORMÁTUS TEMPLOM, 1891-1892}

Következő példánk egy protestáns egyház, a reformátusok fővárosi, Fazekas téri templomának tervpályázata kicsivel kevesebb, mint tíz év múlva. Itt az államtól független, helyi vallásos közösség volt a megbízó. Ennek azért van jelentősége, mert már igen korán találkozunk róla sajtóhírekkel, ${ }^{32}$ sőt az épület elkészülte utáni években is foglalkoztak a templommal. Ez azt is mutatja számunkra, hogy 1892-re már változóban volt az a nézet, hogy az építés, a tervpályázat az építészek magánügye a sajtó területén, az építtető közösség érdeklődése már igen erős volt. A tervpályázatot kísérő sajtóban például olyan cikk is megjelent, amelyben azt kifogásolták a budai lokálpatrióták, hogy Pesten voltak kiállítva a pályatervek, és nem Budán. ${ }^{33}$

A téma kapcsán fontosnak tartjuk, hogy egy másik forrástípusról is említést tegyünk, az elméleti cikkekről. Ezek az ideális református templom építészeti formálásáról szóltak, és nem a konkrét templom építészeti terveiről, mégis fontos előzmények, mert az építészeti megoldások terjedésének egy olyan módjára világítanak rá, amelyről ritkán maradt fenn ilyen jól dokumentálva a „származási vonal”. A cikkek tartalmát csak röviden ismertetjük, a tanulmányunk szempontjából a magyar szakmai nyilvánosságban megjelent képes magyarázatok müfajához tartoznak. Az első ilyen típusú cikket a korábbi példából ismert Schulek Frigyes közölte 1885-ben, ${ }^{34}$ ebben a maga tervezte szegedi református templom többrészes bemutatását terjeszti ki elméleti kérdéssé. Az Épitő Iparban megjelent négy cikkből háromhoz tartozott rajzmelléklet és egyben volt szövegközti ábra. A részletes, mondhatni tanáros dolgozat különlenyomatban is megjelent. Érdekes módon, míg a terveket szinte soha nem írták le, Schulek a geometriai szerkesztést mind szövegesen, mind egyenletekben közli, minden szerkesztést szerkezetileg és kivitelezési szempontból is indokolva. Határozottan oktatási anyaghoz hasonlít a cikk, itt találunk utalásokat a szövegben a képekre: többnyire szabadkozva, hogy ugyan világosan látszik a tárgyalt téma a rajzon, mégis magyarázatot füzött hozzá a szerzö. ${ }^{35}$ A helyszínrajz elcsúszott a szövegbeli említéséhez képest, azonban a geometriai-szerkesztési ábrák olyan szöveghelyre vannak beágyazva, amelyhez tartoznak. Ezek szöveg nélkül teljesen értelmetlenné válnának. Ez a szerkesztés és szövegezés a rajzok és fotók olyan kezelésére utalnak, amelyben a megszokott típusú építészeti terveket megjegyezhetőnek tartották, a szöveghelytől külön kezelték, a bonyolult szerkesztésekkel másként bántak. Feltételezhették, hogy az olvasók egy tervismertetésnél tudják, hogy a szöveg melyik pontján mely tervlapot kell képzeletükbe idézni, szükségtelennek tartották a szövegben ezekre utalást tenni. Ezzel szemben viszont voltak hosszan, nehezen magyarázható képtípusok, amelyeket mi szemléltető ábráknak nevezünk. Ezeket mind a magyar,

\footnotetext{
${ }^{31}$ Ma Szilágyi Dezső tér.

${ }^{32}$ A telket a budai polgárok inkább parknak szerették volna. (J.L. 1893, kiemeli Róka [é. n.] 35.)

${ }^{33}$ A budai református templom. Buda és Vidéke 2 (1893) 20. 8-9.

${ }^{34}$ Schulek 1885.

${ }^{35}$ „A szerkesztési fövonalak az alaprajzba berajzolván is világos képét adják a szervezetnek; de azért mégis szükségesnek tartjuk a következö útbaigazitást." (Schulek 1885. 21.)
} 
mind a bécsi német nyelvü szakirodalom többnyire beépítette a szövegbe az egész időszakban, bár nem mindig írásos utalással, inkább az elhelyezéssel. ${ }^{36}$ Ebből arra is következtetünk, hogy általánosan, a tervekre vonatkozóan a tördelési, technikai nehézségeket nem volt olyan fontos megoldani, mert a szövegnek és a képnek nem kellett szorosabban összetartoznia, csak az volt a fontos, hogy legyen képanyag. ${ }^{37}$ Vélhetően az olvasóközönség nem is igényelte, hogy minden leírt információhoz tartozzon ábra. Az lehetett fontos, hogy az építészeti szakmai kompetenciák segítségével a tervekből, képekből és szövegből az olvasóközönség össze tudja állítani egy épület, egy szerkezet mentális képét a belső fontos szerkezeti elemekkel együtt.

Schulek Frigyes protestáns templomszerkesztésről írt tanulmányát bizonyíthatóan értő szemmel olvasták. A példánkul választott budai református templomot tervező Pecz Samu egy hasonló témában, a Magyar Mérnök- és Építész-Egylet ülésén tartott előadásában és annak leiratában ${ }^{38}$ is utalt rá ${ }^{39}$ hogy Schulek úttörő munkájára alapozott. $^{40}$ Sztehló Ottó pedig egy kisebb templom pályázatát nyerte meg az általános érvényü elemzésre alapozott, Pecz által közkinccsé tett ötszögű alaprajzi megoldással 1890-ben. ${ }^{41}$ Pecz Samu 1888-ban lett a budapesti Múegyetem tanára is, ${ }^{42}$ amikor az említett történetibb és szerkesztések leírása helyett gyakorlati példákat hozó szövegét megírta. Ebben a debreceni Verestemplom szolgáltatta a példát az alaprajz szerkesztésének alaposabb vizsgálatához, a megjelentetett ötszögre szerkesztett alaprajzú templom pedig erősen hasonlít a budai református templom tervére. ${ }^{43}$

A Fazekas téri templom pályázatáról és elkészültéről nemcsak egy bírálóbizottsági jelentést ismerünk, hanem több és más típusú forrás is a rendelkezésünkre áll. A pályázat eredményéről szöveges hírt adott a Vasárnapi Ujság is, ${ }^{44}$ bár a tervekről csak kevés szót ejtett.

${ }^{36}$ Ezt a gyakorlatot követte a Wiener Bauindustrie, a Zeitschrift des Österreichischen Ingenieur- und Architektenverein, a Der Bautechniker és az Allgemeine Bauzeitung; a Der Architekt az egyetlen kivétel.

${ }^{37}$ Erre utalnak az Építő Ipar évindító szerkesztői írásaiban.

${ }^{38}$ Pecz 1888. Az elmélet és a Fazekas téri templom tervezése kétségkívül szoros kapcsolatban van. (Sisa 1998. 216.)

${ }^{39}$ A Schulek által tervezett szegedi református templomot az - egyébként többnyire külföldi példákat felvonultató - illusztrációs anyagban is szerepelteti. (Pecz 1888. 200.)

${ }^{40}$ „Áttérve a kálvinista templom-épület alapalakjának fejtegetésére, kötelességünknek tartjuk fölemlíteni, hogy e téren már Schulek Frigyes tanár mint úttörö szerepel, s jelen értekezésünkben az általa fölvetett eszmék szélesebb alapra helyeztetvén, a fölvetett kérdés talán egy lépéssel elöbbre vitetett.” Fölolvastatott a Magyar Mérnök- és Építész-Egylet mü- és középítészeti szakosztályának 1888. évi február hó 20. és 27-én tartott ülésein. (Pecz 1888. 193.)

${ }^{41}$ A szolnoki református templom pályázatának bírálói a Magyar Mérnök és Építész Egylet tagjai voltak, így ugyan nagyon röviden, de tudósított az Épitö Ipar is. Innen tudhatjuk, hogy a nyerteseknek nem tudtak pályadíjat adni. (A szolnoki református templom. ÉPIP 13 [1890] 403.) A templomról tervezője egy nagyon rövid ismertetést csatolt csak a rajzmellékletben közölt távlati tervhez, a szerkesztésre, a tervezésre nem tért ki. (Sztehló 1892.)

${ }^{42}$ Pecz 1920. 4.

${ }^{43}$ Sándy Gyula, Pecz tanársegédének memoárjából azt is megtudjuk, hogy a korszakban felmerült az a gondolat is, hogy szellemi szabadalomként levédetik a centrális elrendezésű, sokszög alapú alaprajzi szerkesztés módját. (Sándy 2005. 40.)

${ }^{44}$ Református templom Budán. VU 38 (1892) 445. 
A templom pályázati kiírását a kijelölt templomépítő bizottság javaslata alapján 1890. június 28-án tárgyalta az egyháztanács. Olyan pályázatot szerettek volna, amelyen a legjobb építészek mérettetik meg magukat, és jó megoldást találnak a nem túl elönyös telekből adódó nehézségekre. A pályadíjakat nem tudták magasra emelni, ezért inkább hosszabb időt adtak a kidolgozásra: 1890 júliusában hirdették ki a pályázatot, ${ }^{45}$ beadási határidejét 1892. január 1-jében határozták meg, azaz másfél év állt rendelkezésre, ${ }^{46}$ mégis csak négy mü érkezett be. A bírálat hossza többszöröse az évtizeddel korábbi kaposvári jelentésnek, noha a bírálóbizottság kétharmad részt egyezett. ${ }^{47}$ A kaposvári jelentéshez képest lényegesen több „,száraz adatot” tartalmaz, a pályatervek száma, típusa, mellékletei, a tervezési programnak való megfeleléshez pedig a program bizonyos részleteit is leírják - ezzel segítve az érthetőséget annak, aki nem ismerte az elözményeket. Noha az Építö Ipar szerkesztőjének beharangozója szerint: „, Örömünkre szolgál, hogy a fönti nagyon érdekes és tanulságos bíráló jegyzökönyvet közölhetjük s biztos kilátásunk van rá, hogy a pályamüveket is megismertethetjük olvasóinkkal."48 A tervek közlésére nem került sor. A szövegben magukra a müvekre a taxatív bemutatáson túl építészeti-ábrázolásbeli utalások is vannak. Például az egyik pályaterv alkalmatlanságát a következöképpen ecsetelik: „, A templomnak szigorúan katholikus jellegén tehát, az a körülmény, hogy a rajzcartonokon a kikapart katholikus föoltár helyébe a célszerütlen helyzetü református szószék rajzoltatott be utólag, természetesen mit sem változtat." ${ }^{49} \mathrm{Ez}$ az egyáltalán nem burkolt kritikai hangvétel nem volt idegen sem az Épitő Ipartól, sem az Egylet más kiadványaitól, még olvasói levélben is megjelent olykor. ${ }^{50}$ Ez a szakmai közélet általános hangnemének írásos lenyomata, sőt annak minden bizonnyal némileg tompított változata is. A másik rajzi megjelenésre való utalás már dicséret: „, A hatszögü csillagban aranyos $C$ betü $B$ ” jeligéjű pályaterv értékelésében kiemelik, hogy az ábrázolás nagyon könnyed és tetszetős. ${ }^{51}$

${ }^{45}$ Pályázati hirdetmény. VL 11 (1890) 2.

${ }^{46} \mathrm{~A}$ budapest-pesti ev. reform. Egyháztanács és közgyülés jegyzőkönyve 1894-1896. 96. Kézirat a Dunamelléki Református Egyházkerület Ráday Levéltárában. Kiemeli: Róka [é. n.] 49.

${ }^{47}$ Bíráló jegyzőkönyv. ÉPIP 15 (1892) 187-188, 195-197, 203-204. A bírálók: Czigler Győző, Schulek Frigyes és Kiss István voltak. Utóbbi Budapesten kezdte építész tanulmányait a József Müegyetemen, majd Theophil Hansen és Friedrich von Schmidt tanítványa lett. Még budapesti tanulmányai alatt tanársegéd volt, később kinevezett magántanár az Egyetemen. (Szinnyei 1899. 301-302.) Így Kiss is a tanári hozzáállást erősítette a bizottságban.

${ }^{48}$ Bíráló jegyzőkönyv. ÉPIP 15 (1892) 187.

${ }^{49}$ Uo.

${ }^{50}$ „Lapunk kiadó hivatalának irt s a szerkesztöséghez címzett levelére a felelettel azért maradtunk eddig adósak, mert tulajdonképen nem tudtuk, ránk tartozik-e a dolog, használván Ön háromféle (»Épitési ipar«, »Építési Közlöny« és »Közlöny«) címet. Végre mégis meggyöződtünk, hogy »Az Építési Ipar«-t akarta Ön érteni. [...] Ha így fogja fel a reklamátiót, igen sajnáljuk, de nem érthetünk Önnel egyet. Ily értelmezés tönkre tenne minden hirlap-irodalmi vállalatot, mert egy példány helyett kettöt adni a különben is csekély elöfizetési dij mellett, csakugyan lehetetlen. [...] kérjük a kiadó hivatalunk által már jelzett irtat követni." Szerkesztői üzenet. ÉPIP 2 (1878) 384.

${ }^{51}$ Bíráló jegyzőkönyv. ÉPIP 15 (1892) 197. 
A templomtervek értékelésében előfordul leírás is, de nem önállóan, hanem mindig az értékelés részeként. A jegyzőkönyv az értékelés szempontjait következetesen vette végig, a szóhasználat is ismétlő, bár nem állandó: az alapkoncepció, használati elemzés, térhatás, árnyékhatás és világítás, stabilitás - azaz a szerkezetek állékonysága -, külső architektúra, különösen az egymáshoz viszonyított arányok és harmónia, végül az összegzés. A funkcióelemzés minden esetben nagyon érzékletesen követi a tervben elképzelt épületek használatát, milyen volna, ha azok megépülnének, ezen a módon támasztják alá ítéletüket a bírálók. Ez a megközelítés azért volt szükségszerü, mert a megbízók az értékelésre kérték fel őket, de a végső ítéletet az építészetben laikus, az egyháztanács által kijelölt templomépítő bizottság tagjai hozták meg. Ök biztosan igényelték az alapos indoklást és a képletes leírást, amely alapján a felkért szakértők értékeltek. A templomépítő bizottság elfogadta az alapos munkát végző bírálóbizottság javaslatát és Pecz Samut bízták meg a templom tervezésével és a müvezetéssel. ${ }^{52}$ A pályatervek közül csak a nyertesét ismerjük, ${ }^{53}$ azt is Pecz Samu hagyatékából, nem a korabeli publikációból. A nyertes pályamü készítéséről nemcsak értékelés maradt fenn, hanem részletes leírás is készülésének körülményeiről. Sándy Gyula - Pecz munkatársa - memoárjában leginkább a rajzolás nehézégeit ecseteli. ${ }^{54}$ A kiviteli tervek készítése kapcsán ír az alkotó folyamatról, az építészeti példák és a szakirodalom használatáról. Pecznek munkaügyben el kellett mennie Budapestről, így a rövid határidő miatt Sándyra maradt előzetes megbeszélés nélkül a torony megtervezése. Így ír a tervezésről: „Elö is vettem a szertárban lévő, mint itthoni anyagkészletemet, és böszen tanulmányoztam a müemlék-toronyformákat és a legújabb közleményeket a középkori stílben készült modern tornyokról, ezek közt Otzen munkáit, amik közül mélyebben elmerültem azok rajzainak szemlélésében, amiket tanulmányutam alkalmával természetben is láttam. Ekképp felfegyverkezve hozzáfogtam »eszem exerciroztatásához "és papírra vetettem amint azt magamnak megálmodtam [...] Pecz nézi egy darabig majd [...] fogai között morogva mondta ki az itéletet: "Szép, szép Sándy úr ez a torony, de hát Otzennek is megvan a maga esze, és más embernek is megvan a maga esze«. [...] Ugy látszik a kelleténél tüzetesebben tanulmányoztam Otzen munkáit és emlékeztem vissza tanulmányutamon nagy élvezettel látott Otzen tornyaira. Ezt a mély benyomást Pecz azonnal felismerte. A vége az lett, hogy szép toronytervemet sutba kellett tennem és a budai ref. templom tornya más ember esze szerint lett megtervezve." 55 Jól mutatja Sándy szövege, hogy a kreatív alkotást már akkoriban sem fogalmi úton megfogható folyamatként látták. Az oktatás történelmi szemlélete és a stílusban tervezés alapján akár azt a következtetést is levonhatnánk, hogy mintakönyvekből, készen kapható megoldások begyakorlásával lehetett tervezni, de mint példánk is mutatja a magas színvonalú építészeti alkotás akkor is több volt a minták puszta kombinálásánál. A historizmus, bár történelmi példákkal dolgozott, de kreatívan használta és nem másolta öket. Ebből a részletből

\footnotetext{
${ }^{52}$ Róka [é. n.] 71.

${ }^{53}$ MNLOL T 6 No. 30./1-7.

${ }^{54}$ Sándy 2005. 41.

${ }^{55}$ I. m. 49.
} 

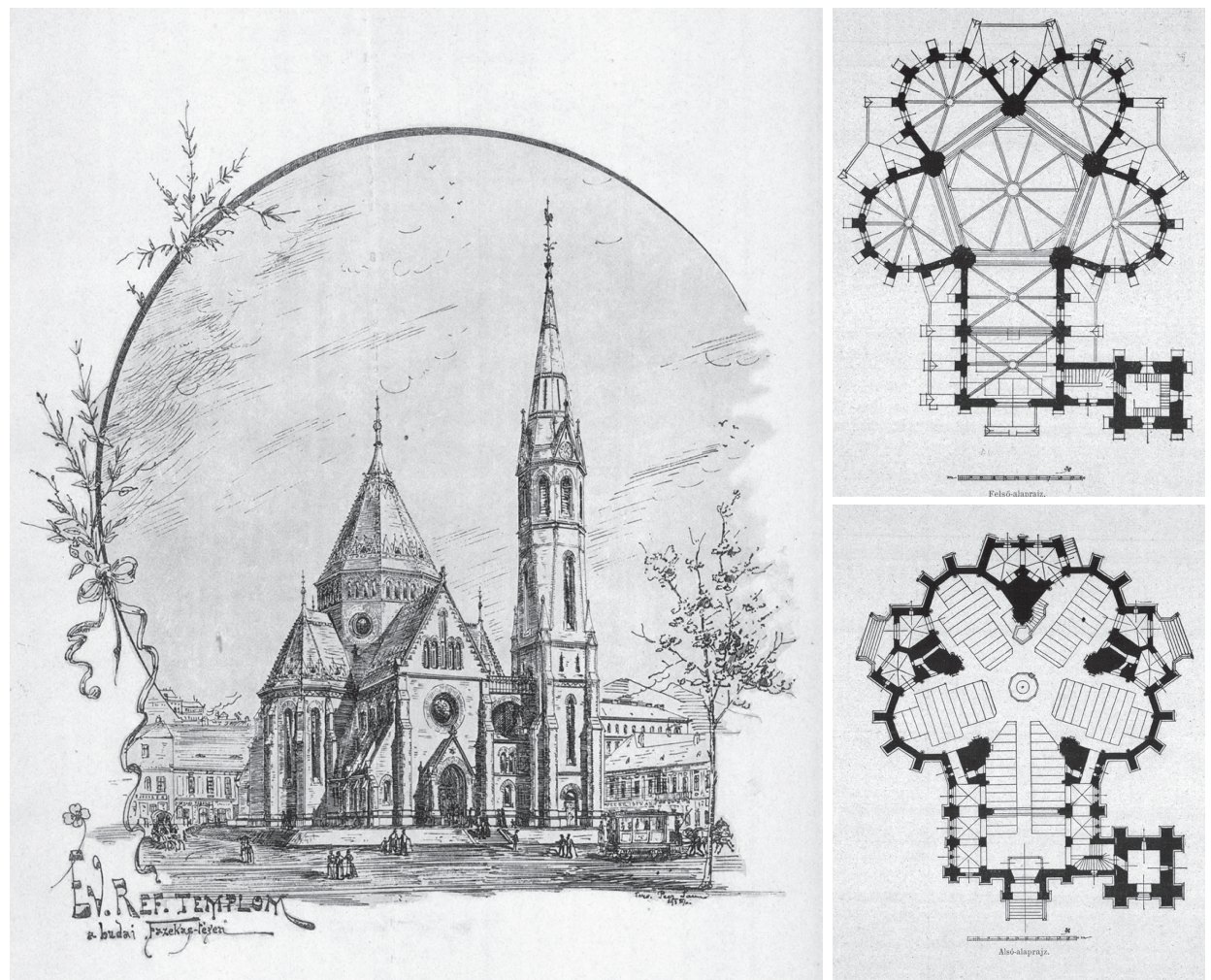

2. ábra. A Fazekas téri református templom távlati képe és alaprajzai (ÉPIP 18 [1895] melléklet, 41)

azonban azt is megtudjuk, hogy - valószínúleg az oktatásból vett rutin szerint - létező szokás volt a tervezéshez kurrens szakirodalmat olvasni, de a hozzá tartozó tervek, képek, és föként a személyes látogatás szereplőinknek sokkal fontosabbak voltak. Ez a gondolkodásmód nyilvánvalóan a szakmai folyóiratok szerkesztőségét és közönségüket is jellemezte.

A már majdnem kész épületet háromrészes cikkben mutatta be Sándy Gyula, és rajzmelléklet is megjelent az Épitö Iparban. ${ }^{56}$ Sándy föként az építésnek a gyakorló építész szemszögéből megélt történetét írta le három részben. A második részben tárgyalta részletesen a telekből adódó kivitelezési nehézségeket, a liturgiai alapokból kiinduló tervezés történetét, leírta a templom belső és külső kialakítását, a bemutatásban konkrét méretek is tartoztak a szöveghez. Ehhez kapcsolódott mellékletként a majdnem kész templom végleges tervei közül egy látványos távlati kép, dekoratív florális díszü - már-már szecessziós - keretben, amelynek aláírása Pecz Samut jelöl-

${ }^{56}$ Sándy 1895. 
te meg, de rajzolója Sándy Gyula volt (2. ábra). ${ }^{57}$ Ilyen grafikai megoldás a magyar szakirodalomban ritka, az osztrák lapokban és az 1880-as évek általános sajtójában ${ }^{58}$ rendszeresen jelentek meg különleges rajzi megoldásokkal operáló tervek. ${ }^{59}$

A felavatásról a Vasárnapi Ujság számolt be az építés történetét is ismertetve, még a tervezőről, Pecz Samuról is közöltek fotót ${ }^{60}$ A szövegben a szerző Kiss Áron valószínúleg a könnyebb érthetőség kedvéért, az alaprajz alapalakját, az ötszöget inkább csillagnak mondta, az alapötszög oldalaihoz csatlakozó tízszögletes fülkéket pedig karéjoknak nevezte. A stílust először csúcsíves szabásúnak titulálta, majd később ugyanebben a szövegben a korabeli szakszerübb megnevezést, a korai „góth stylus"-t használta. Az épületről készült, viszonylag nagy méretben közölt fotóra is utalt egyben, hogy ez ott jól megfigyelhető. Az épület arányainak megértéséhez sok méretet szerepeltetett a szövegben. A cikk azonban - megjelenési helyének megfelelően - inkább a társasági eseményt, a vallásos közösség számára fontos tényezőket részletezte, építészeti fejtegetésbe nem ment bele. Pár évvel a felavatás után az osztrák szecesszió lapja is két képpel ellátott cikket szentelt az épületnek a magyar millenniumi építkezéseket bemutató anyag részleteként. ${ }^{61} \mathrm{~A}$ szöveg a funkciók megnevezésével szakszerủ leírása a templom belső kialakításának, tömegének. Említi a szerkesztési elvet, anyaghasználatot, végül a díszítést és a berendezést, valamint az anyagiakra való hivatkozást annak szerénysége miatt. ${ }^{62} \mathrm{~A}$ kapcsolódó illusztrációk a tervezők számára legfontosabb elemeket mutatják: az Úrasztalt, az egész épület középpontját és a két szint alaprajzát, léptékkel, aláírással. A képaláírás és a cikk címe is pontos, megnevezi a tervezőt és megadja a titulusát is, a belsőt ábrázoló fénykép készítője viszont ismeretlen marad. ${ }^{63}$ Tördelés szempontjából a fotó egy másik magyar épület leírása mellett kapott - eléggé kényszeredett - helyet.

Pecz önéletírásában több oldalt szentelt a templom építésének. ${ }^{64}$ Eddig csak a beosztott munkatárs - Sándy Gyula - visszaemlékezése került szóba, Pecz Samu memoárjában nagyon szikáran írja le az építés történetét, a templomot esszenciális vonásaival ismerteti, magát csak párszor említi benne, a motivációról vagy kivitelezésről is csak nagyon röviden, szakmai szempontból írt, és ábraanyag nem kapcsolódik a kézirathoz. Egyikőjük sem említette azt a kritikát, amelyet a magyar mủvészettörténet legnagyobb hatású mủvészetfilozófusa, Fülep Lajos írt 1918-ban, amely-

\footnotetext{
${ }^{57}$ Sándy 2005. 40, 116. Ez a rajz nem azonos avval, ami a fóváros megrendelésére az ezredéves kiállításra készült.

${ }^{58} \mathrm{VU} 31$ (1884) 517.

${ }^{59}$ Ilyenek a kollázsszerü kompozíciók, a trompe o’leil módszerrel közölt tervek és a wagneri hatású rajzkeretezések.

${ }^{60}$ K.Á. 1896, a szerző valószínüleg Kiss Áron, akinek a felolvasását idézi a cikk.

${ }^{61}$ Der neue Calvinerkirche in Budapest. Der Architekt 3 (1897) 5-6.

${ }^{62} \mathrm{Ez}$ a tartalmi szerkezet, a leírás objektivitása, a magyar „Úr asztala” megnevezés tükörfordításának, a „Tisch des Herrn” szónak - és nem a német liturgiában szokásos „Abendmahlstisch” kifejezésnek - a használata, és az, hogy Pecz nevét itt helyesen használják - miközben máshol sok névalakban, de szinte sosem helyesen jelent meg -, egyértelmüvé teszik, hogy a szerző magyar volt.

${ }^{63}$ Noha a lapszámban megjelent rajzok szignáltak (Grüner).

${ }^{64}$ Pecz 1920. A másik memoár 1950-53 között készült: Sándy 2005.
} 
ben azzal vádolja Peczet, hogy csak a gótikus stílus illusztrálása vezette a templom tervezésében - ehhez a szöveghez semmilyen kép nem tartozott, csak az 1974-ben gyüjteményes kötetben megjelent verzióhoz válogatott illusztrációkat a szerző. ${ }^{65}$ Fülep - itt a leginkább tetten érhetően tévedésen alapuló - hozzáállása hosszú évtizedekig befolyásolta nemcsak a templom recepcióját, de az egész korszak historizáló építészetének megítélését is. Az általa meghonosított pejoratív értelmű eklektika megnevezés csak lassan kopott ki a szakértők szókészletéből, a laikusok szóhasználatában ma is gyakran elöfordul.

\section{BUDAPEST, LIPÓTVÁROSI ZSINAGÓGA 1898-1899}

A magyar állam ezeréves ünnepsége, a Millennium óriási fellendülést hozott az építő iparnak. Korszakunkban a folyóiratok, megjelenések számát és minőségét tekintve a leggazdagabb időszaka az 1890-es évek közepétől egészen az első világháború nehézségeinek begyürüzéséig, az 1910-es évek közepéig tartó nagyjából tíz év. Az 1896-os millenniumi ünnepségek lezárultával azonban ez a gazdasági hatás múlni látszott, az építőipar 1899-1903 között súlyos válságot élt meg, az építészek a sajtóban is sokat panaszkodtak róla, hogy kevesebb lett a megbízás. ${ }^{66}$ Ezzel egyidőben azonban nagyon fontos pályázatok zajlottak a századforduló időszakában. Közülük publicitásában kiemelkedik a nagy lélekszámú budapesti zsidó közösség belvárosi, 3600 fő befogadására alkalmas „szuperzsinagógájára” kiírt nyílt, jeligés pályázat, amelyre nagyon sok, 23 pályázati mủ érkezett be. Érdekes, hogy éppen ezt a kiírást nem közölte egyik építészeti szakfolyóirat sem, csak a saját definíciója szerint zsidó felekezeti jellegü politikai és szépirodalmi közlöny, az Egyenlöség. A hetilap 1898. február 20-i számában nemcsak hírt adtak a pályázatról, de rögtön az egész programot is közölték. ${ }^{67}$ Az Építö Ipar csak arról írt korábban, hogy várható a pályázat. ${ }^{68}$ A határidő a Fazekas téri református templomhoz hasonlóan szintén meszszi volt, az eredeti, 9 hónapos leadási időt még meg is hosszabbították 1899. február 1-ig, így majdnem egy év állt a pályázók rendelkezésére. A beérkezett müvekből készült kiállítással ${ }^{69}$ pont egy időben volt az ország legjelentősebb közgyüjteményére - a budapesti Szépmúvészeti Múzeum épületére - kiírt pályázat anyagának be-

${ }^{65}$ „pl. a Szilágyi Dezső téri ref. templomot, amely nem rendeltetési céljára, hanem annak egyenes rovására készült a gótikus stílus iskolai illusztrálása kedvéért, amelyben épp azt nem lehet csinálni, amire való volna, prédikálni, szóval amely létének legelemibb föltételét sem teljesiti - a kicsiböl is megérthetni az épitészetnek a konstruktív szellem kiveszésével s a történeti stilusok értelmetlen kultuszával egy század leforgása alatt megérett mérhetetlen, tovább már alig fokozható romlását." (Fülep 1918.)

${ }^{66}$ Ezen építőipari válságot Széll Kálmán kormányának drasztikus kiadáscsökkentése okozta, amellyel a megelőző fél évtizedben a millenniumi építkezések generálta költekezést kívánták ellensúlyozni. (ÉPIP 24 [1901] 150, 243; ÉPIP 25 [1902] 163, 342.)

${ }^{67}$ A Lipótvárosban építendő új templom pályázati programmja. Egyenlöség 12 (1898) 8. 12-13.

${ }^{68}$ ÉPIP 22 (1898) 12.

${ }^{69}$ A kiállítást a bírálati jegyzőkönyv elkészülte után nyitották meg a nagyközönségnek. (PV 3 [1899] 8. 4.) 
mutatása is, személyi egyezés is van a két verseny mezőnyében. ${ }^{70} \mathrm{~A}$ két pályázatot többször említették együtt a cikkekben, ${ }^{71}$ és az összehasonlításból mindig a zsinagóga versenye került ki győztesen, a múzeum pályázatára csak kilenc pályamü érkezett be. Az építészetileg kihívást jelentő téma mint feladat is vonzó lehetett, hiszen ahogy a református templom ideális tervével - itt is egy típust lehetett megalkotni. Másrészről a díjak is viszonylag magasnak számítottak a korban: az elsődíjas tervet 3000, a másodikat 2000 forinttal jutalmazták. ${ }^{72}$ Nemcsak mennyiségében, de müvészeti megoldásaiban is egyértelműen jobbnak tartották a zsinagóga pályázati anyagát, elfogulatlannak és a protekciónak nemesen ellenállónak a zsürit, aki a fiatal tehetségeket díjazta. ${ }^{73}$ Ezzel kapcsolatban a megbízókat is dicsérték, hogy a bírák minden nyomás nélkül dönthettek, a müvészi szempontokat vették figyelembe, és a kitünő terveknek anyagi elismerést is megítélhettek a dicséret mellé. Annak ellenére, hogy az adott költségvetésbe egy terv sem fért bele, és átdolgozás nélkül kivitelre egyet sem javasoltak, részletesen bírálták az összes tervet. ${ }^{74}$ A nyertes a Foerk Ernő és Schömer Ferenc páros volt „,Alef”, a második Bálint Zoltán és Jámbor Lajos párosa „Mózes”, a harmadik Leitersdorfer (Lajta) Béla „Rajzolt hexagramm 5659” jeligéjü tervükkel. Megdicsértek további hat tervet: Scheer Izidor, Vágó László és Vágó József (,,Nyolc lépcsőház”); Márkus Géza (,Non ebur nec aurea”); Schickedanz Albert és Herzog Fülöp (,,rajzolt Hétágú gyertyatartó”), Baumhorn Lipót (,,5659”); Freund Vilmos („Hit és remény”); Kármán és Ullmann (,Rajzolt Mózes fej”). A megdicsért tervek közül csak Freund Vilmoséról nem jelent meg semmilyen ábrázolás, de a tervsorozatok közül több is van, amelynek épp a három fő lapját (alaprajz, metszet, homlokzat vagy távlat) nem közölték. ${ }^{75}$ Az ismert tervek a századfordulón népszerü építészeti megközelítések széles palettáját vonultatják fel, izgalmas tervezési megoldásokkal, a maga korában és több mint száz évvel később is témát adva az elemzőknek.

A bőséges cikk-kínálatot két részre osztjuk: amelyikhez tartozik illusztráció és amelyikhez nem. Ez a megkülönböztetés a médiumok típusa szerint is érvényes, az illusztrált ismertetések mind hetilapokban, döntően szaklapokban, a csak szöveges

\footnotetext{
${ }^{70}$ Például Schickedanz Albert és Herzog Fülöp indult mindkét pályázaton, mindkét zsűri munkájában részt vett Hauszmann Alajos és Schulek Frigyes. (ÉPIP 23 [1899] 81; H. Gaal 1899.)

${ }^{71}$ Palóczy 1899; P[aur] 1899; Tar 1899; Neues Pester Journal 20 (1899) 14. 1.

${ }^{72}$ A díjak a programmal együtt jelentek meg. (A Lipótvárosban építendő új templom pályázati programmja. Egyenlöség 12 [1898] 12-13.) A múzeum pályázatán kétszer magasabb díjazásért versengtek. (ÉPIP 23 [1899] 81.)

${ }^{73}$ Haber figyelt, ügyelt arra, hogy a laikusok számára bemutassa a zsüri tagjait. „,A jury a pestihitközség elnökéből, Kokner Zsigmondból, két elöljárósági tagból: Deutsch Sámuel és Baumgarten Lajosból, König Károly, a bécsi politechnika tanárából, Stiaszny Vilmos, bécsi müépitöböl, Alpár Ignáczból, a mérnök és épitész egyesület képviselőjéböl, Bakos Jánosból, a székesfövárosi közmunkák tanácsának tagjából, Heuffel Adolfból, a székesföváros középitési igazgatójából, Hausmann Alajos müépitö, a m. kir. müegyetem tanárából, Schulek Frigyes müépitö, az orsz. mintarajziskola és rajztanár-képzö tanárából és Steindl Imre müépitö, a m. kir. müegyetem tanárából alakult." (Haber 1899.)

${ }^{74}$ Haber 1899; PH 59 (1899) 8. 6.

${ }^{75}$ Ismerjük még Schickedanz Albert - Herczog Fülöp teljes tervsorozatát (MNL OL T 7 - No. 1/1-113., T 7 - No. 2/1-41), ezeket terveket a korabeli sajtó nem publikálta.
} 
cikkek pedig a napisajtóban jelentek meg. Az ábraanyag közlése a korábbiakhoz képest sokat fejlödött: a Vasárnapi Ujságban jelent meg a Schickedanz és Herzog páros, Lajta Béla, Bálint és Jámbor páros terveinek távlatrajza, valamint a Márkus Géza makettjéről készült fotó (3. ábra), ${ }^{76}$ utóbbi kifejezetten újdonságnak számított. ${ }^{77}$ Az előző példánkhoz, a Fazekas téri református templomhoz képest a magyar szaksajtóban erre az időre eltünt az illusztrációkról a fotós vagy a sokszorosító vállalat neve. Az Egyenlöség című hetilap amúgy rendkívül kevés képet közölt, és az ábrák általában nagyon rossz minőségüek voltak, de ebben az esetben bemutatták a nyertes terv föhomlokzatát, a második és harmadik díjas terv távlatát. Szinte természetes, hogy a családi lapokban nem voltak alaprajzok, csak távlati képek, de az Ungarische Bauzeitung szakfolyóiratban is csak két távlatot közöltek, a második és harmadik díjazott tervét. ${ }^{78}$ Ahogy említettük, a szakmai sajtóban érdekes módon nem jelent meg a kiírás, és a pályázatról sem tudósítottak bőségesen. Az Épitö Iparban ugyan ígérték, ${ }^{79}$ hogy majd bővebben közölnek képeket, de pár lap kivételével ez elmaradt, ${ }^{80}$ nem is írtak bővebben a tervekröl. Az Egylet Közlönye azonban hosszú elemző cikket szentelt a témának, amelyet $\mathrm{H}$. Gaál Adorján, a Budapesti Magyar Királyi Állami Felső Építő Ipariskola tanára írt. Valószínűleg ez is többrészes lett volna, mert csak az elsődíjas tervet elemezte, és képet is csak erről közöltek. ${ }^{81}$ A szövegekben egyre többször reflektálnak a tervek által fejben összerakható térhatásra, ez különösen H. Gaál cikkében figyelhető meg. A következő szófordulatokkal él: „, különösen ahová a szem a belsö térhatás megitélésénél okvetetlenül odatéved”, vagy „, közvetetlenül térhatásukban nem is szemlélhetö". ${ }^{82}$ Utal továbbá arra is, hogy amit a rajzról le tudunk olvasni, nem biztos, hogy tömegében is ugyanazt a hatást fogja kelteni, mint amit így elképzelünk. Például a kupola a homlokzati rajzon túlságosan nagynak tünik, de a valóságban a térhatása sokkal kedvezőbb lesz, mert a valódi perspektívában mindenképpen kisebbnek fog tünni és belesimul majd a környezetbe. Sőt azt is írja, hogy ezzel a jelenséggel kapcsolatban biztos benne, hogy az építészek a hatást számításba vették, azért terveztek így. A szerző tanítói rutinjának is betudható, hogy ebben a cikkben már ábrázolás is található a szöveg mellett, és nem is szabadkozik a magyarázat miatt, mint Schulek - a Fazekas téri templom előzményeként bemutatott, református templomok ideálterveiről szóló írásában. A leírás azonban itt is kiegészül valamennyire a tervek térbeli hatásának leírásával: „Az alaprajz a görög keresztalakból indul ki, melynek magját a négyzet, mint kupo-

\footnotetext{
${ }^{76} \mathrm{P}[\mathrm{aur}] 1899$.

${ }^{77} \mathrm{~A}$ makettek elsősorban a laikus közönség megszólítására készültek, valószínűleg a sajtó Márkus iránti feltétlen lelkesedését is jelentősen segítette. A Hét című folyóiratban megjelent hosszú cikk esztétikailag igen képzett, de építészeti területen laikus szerzője - Tar Lőrinc, aki a Nyugat későbbi szerkesztőjeként már az Ignotus nevet használta - egyenesen rajongott a tervekért, és a tehetség megmutatkozását vélte megjelenni a dúsan díszített magyaros tervlapokon. (Tar 1899.)

${ }^{78}$ Sommer 1899.

${ }^{79}$ ÉPIP 23 (1899) 90.

${ }^{80}$ ÉPIP 23 (1899) 87, 88, 89, 90, 103, 104.

${ }^{81}$ H. Gaal 1899. VII-VIII. rajzmelléklet.

${ }^{82}$ I. m. $125,126$.
} 
latér alkotja. A kereszt szárnyait a karzatok foglalják el, míg a föhomlokzat felé nyúló ágat elöcsarnokszerü építmény bövíti meg. Az egész elrendezésnek, az elöcsarnok és az épületnek evvel szemben levö oldalához csatolt mellékhelyiségeket magában foglaló csoportozata, hosszúkás alakot kölcsönöz, mely körülmény a kupolának külső térhatását csak kedvezőbbé teszi." ${ }^{83}$ Ezt a fajta térkompozíció-összeállító mentális képességet a korábbi írott szövegek nem nevesítik, nem emelik ki.

A már említett, Építö Iparban megjelent cikk igazából nem is a zsinagóga pályázatáról szólt, hanem valóban két tervpályázat, a zsinagóga és a Szépmúvészeti Múzeum összevetése. ${ }^{84}$ Eszerint értékelhetjük Palóczy Antal írását, aki gyakorlott szakíró és egyébként H. Gaál Adorján tanártársa volt. Dicsérte a nyertes Foerk Ernő - Schömer Ferenc páros rajzainak bámulatos virtuozitását; a metszetet, amely a kupolát feltárja egyenesen fenomenálisnak nevezte; és a belső térhatását is említi. A többi díjazott és dicséretben részesült tervet rövidebben írta le, állandó szempontrendszerrel, de nem kötött sorrendben. Általában a stílus és az alaprajzi- vagy téralakítás az értékelés elejére került. Ezenkívül mindig a fontos, jellegzetes elemeket emelte ki. A szöveg tördelését tekintve illeszkedik az Építö Ipar ekkoriban jellemző képszerkesztési szokásaihoz: a cikkben az első illusztráció a szinte teljes oldaltükröt elfoglaló három terv a máriaremetei Boldogasszony-kápolnáról, amelyet ugyan az egyik nyertes pályázó, Schömer Ferenc tervezett, de semmi köze nem volt a két pályázathoz, amelyröl a szöveg szólt. A cikk végén csak ahhoz füztek magyarázatot, hogy miért a harmadik díjas tervanyagot közölték: ezt szerezték meg a leghamarabb. A pályamüvek képes bemutatása nemcsak hiányos volt, de a nyertes tervek is teljesen más cikkek mellett, nem is egymás után jelentek meg később. ${ }^{85}$ Palóczi cikke a korabeli pályázati szakirodalomban mondhatni általánosnak mondható mind felépítés, mind lényeges pontok kiemelése ügyében. Az illusztrált, szakmai cikkek közül az Ungarisches Bauzeitungot már említettük, Josef Sommer cikke tartalmát tekintve az addig megjelent cikkeket összegezte ${ }^{86}$ és inkább benyomásokat írt le, sem funkcióelemzést, sem térlátást igénylő összefüggéseket nem közölt. Építész által írt cikk jelent még meg az Épitészeti Szemlében is. ${ }^{87}$ A (T.) néven író szerző cikkének már az elején a konkrét tervlapok megjelenésére vonatkozó összegző megállapításokat tett; hogy sok lap részletgazdag, múvészi kialakítású, és van köztük pár szép akvarell is. Majd az egyes tervek közül az első két díjazott pályamü értékelését is azzal kezdte, hogy a rajzi megjelenés milyen. A nyertes pályamü stílusából pedig csak egy konklúziót vont le: Foerk és Schömer Steindl Imre asszisztensei, az Országház terveinek hatásától nem tudtak szabadulni. A térhatás említése itt sem marad el: a Foerk-Schömertervröl írta, hogy szerinte a tervrajzon jobban fest, mintha megépülne, mert hatása

\footnotetext{
${ }^{83}$ I. m. 126.

${ }^{84}$ Palóczy 1899. 85.

${ }^{85}$ ÉPIP 23 (1899) 96, 103, 104.

${ }^{86}$ Részben a hibákat is átvéve, a Vasárnapi Ujságban megjelent rossz számot közölte újra, mely szerint 14 mü érkezett be. (Sommer 1899. 97.)

${ }^{87}$ T. 1899.
} 


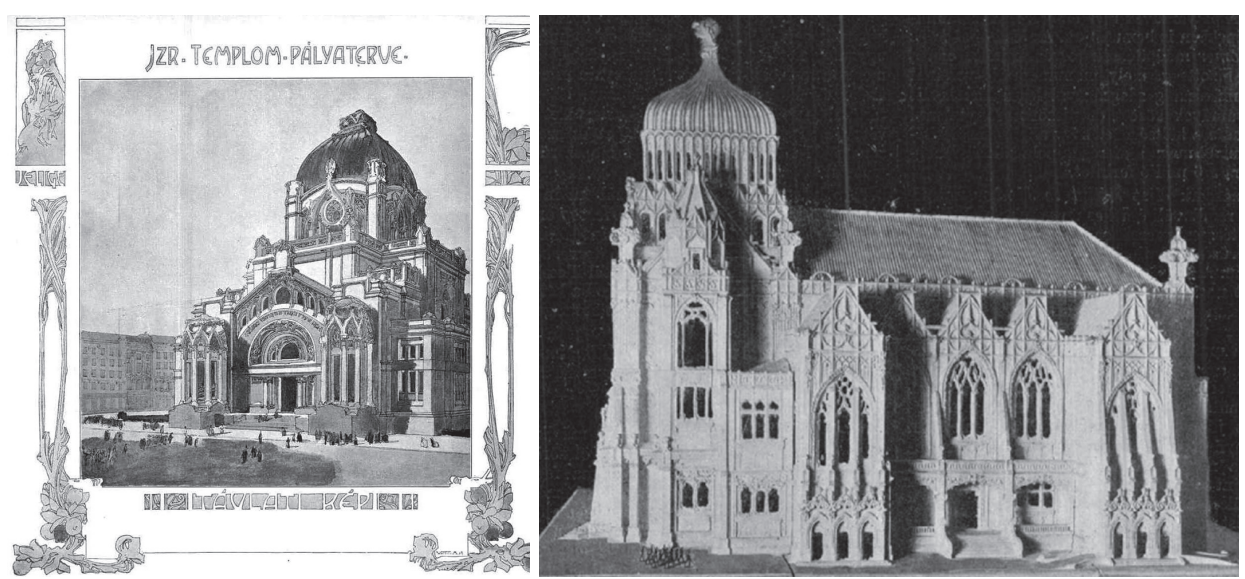

3. ábra. Lipótvárosi zsinagóga, a Kármán-Ullmann páros tervének távlati képe és a Márkus Géza modelljéről készült fotó (Der Architekt 5 [1899] 88; VU 46 [1899] 201)

nyugtalan lenne a sok részlettől. A szerző a második díjas Bálint és Jámbor páros tervét keresetlenebbnek, az építészeti kialakításában szerencsésebbnek tartotta.

Mint láttuk, újdonságként a rutinosabb szakíróknál megfigyelhető a térhatás említésén túl, hogy egyre több megjegyzést tesznek a pályatervek rajzi megjelenésére. Ez nem véletlen, hiszen a bécsi szecesszió hatása ekkor gyürüzött be Budapestre, amelynek - rajzi szempontból - egyik ismertetőjegye az ornamentális díszekkel dúsan keretezett tervlap és általánosságban a grafikai megjelenítés fókuszba kerülése. Bár Magyarországon ennek a stílusirányzatnak nem sok követője volt, nem is jelent meg magyar nyelvủ szaksajtóban a pályázat egy dicséretben részesített tervsorozata, a szecessziót követő Kármán Aladár és Ullmann Gyula páros munkája (3. ábra). Ezt csak a Der Architekt folyóiratból ismerjük: a kapcsolódó leírás a magyar építészek „modern” stílussal szembeni ellenérzését említi. ${ }^{88} \mathrm{Ez}$ a kritika felszínes volt, hiszen a második és harmadik helyezett pályamü is a korszakban használatos modern jelzőt kapta, tehát a zsürinek nem volt gondja ezzel. Az osztrák lapban csakúgy, mint máskor, nem írtak bőségesen a tervekről. Azonban itt jelent meg a legtöbb terv, ${ }^{89}$ olyanok is, amelyeket Magyarországon csak a kiállításon lehetett megnézni - különösen a századfordulós stílusú tervekre igaz ez -, viszont a nyertes tervet egyáltalán nem

\footnotetext{
${ }^{88}$, ,Anknüpfend an unsere Veröffentlichung, die Concurrenz für die Synagoge der Leopoldstadt in Budapest betreffend, reproducieren wir den Entwurf der Architekten Aladär Kärmän und Julius v. Ullmann. Dieser Entwurf hat durch selbständige Auffassung und moderne Bearbeitung gothisierender Elemente gerechtes Aufsehen erregt. Klare, einfache Grundrissgestaltung, sowie monumentale Gliederung, vereint mit dem glücklich getroffenen mosaischen Tempelcharakter, zwangen die der modernen Richtung feindliche Jury, dem Entwurf eine Belobung zuzuerkennen." (Concurrenzpläne für die Synagoge in der Leopoldstadt in Budapest. Der Architekt 5 [1899] 39.)

${ }^{89}$ Concurrenzpläne für die Synagoge in der Leopoldstadt in Budapest. Der Architekt 5 (1899) 26-27, 30-31, $39-40$.
} 
közölték. A második díjas terv leírásában foglalták össze a pályázat programját, a szövegrészhez tartozó terv is máshova került, szerkesztésileg itt sem tartoztak össze.

A kiállítás kiemelt társasági eseménynek számított, a napilapok közül több is beszámolt róla.$^{90}$ A pályázat ügye kilépett az építészek szük szakmai szférájából, sőt némiképp ki is csúszott a kezükből: a kiállítóknak a nagy olvasótáborral rendelkezö napilapok fontosabbak lettek, mint a szaksajtó, ami ennek hangot is adott. ${ }^{91} \mathrm{Az}$ Egyenlöségben megjelent hosszú cikk szerzője meg is említette a kiemelt érdeklődést a napi sajtótól, és hozzátette, hogy a napilapok csak általános szempontokat vizsgálva mondtak önálló véleményt. ${ }^{92}$ Ennek okát a szerző abban látta, hogy lelkiismeretesen nem is vállalkozhattak a cikkírók a rövid megtekintés után saját, szilárd alapokon nyugvó vélemény kialakításra. Ezek a beszámolók egybehangzóak lettek, és szinte csak a zsüri ítéletét ismételték. ${ }^{93} \mathrm{~A}$ jegyzőkönyv teljes szövege a sajtóban nem is jelent meg, ma az egyik nyertes pályázó, Foerk Ernő hagyatékából ismerjük. ${ }^{94}$ A nyertesekre vonatkozó részét azonban publikálta az Egyenlöség című lap. ${ }^{95}$ Kiolvasható belőle egy kötött szempontrendszer és sorrendiség, amely inkább a kezdeti, kaposvári jegyzőkönyv szerkezetére hasonlít: először a stílus, a tömeg leírása, megítélése szerepel. Más, a tervekről írt publikációban is ezt láttuk: Palóczy is általában a stílussal kezdte az értékelést, ${ }^{96}$ és a laikus sajtó is jellemzően ezt a témát emelte ki, bár az ott használt szakszókincs vegyes képet mutat.

A Vasárnapi Ujság ábraanyagát már említettük, ${ }^{97}$ a hozzá tartozó szövegben elég sok az építészeti leírás, mely az ábrázolásra is utal. Egyrészt tömegformálásra vonatkozó megjegyzésekkel kezdődött a legtöbb értékelés, és sokat foglalkoztak a stílussal, legyen az belső vagy külső. Ezek a meghatározások nem voltak szakmaiak, és olyan szófordulatokat, kifejezéseket alkalmaztak, amelyeket szakíró nem nagyon írt volna le, mint a „túltömött díszités”. A Fazekas téri templom felavatásakor közölt leíráshoz képest viszont a szöveg határozottan építészeti tematikájú.

Haber Samu publicista, a pályázat egyik legfontosabb hírmondója, az Egyenlöség folyóiratban közölt egy hosszú, az építés szinte minden vonatkozására kiterjedő cikket, amelyben az okoktói és a pályázati programtól kezdve a tervekből készült kiállítás megtekintéséhez tartozó praktikus információkig sok mindenről tájékozódhatott az olvasó. A cikk nagy részét nem ő írta, hanem idézte, és alcímekkel jól áttekinthe-

${ }^{90}$ PH 59 (1899) 8. 5-6; PV 3 (1899) 8. 4; BH 19 (1899) március 9., 6-7; PL 46 (1899) március 11., melléklet; PL 46 (1899) március 2., melléklet; PL 46 (1899) március 31., melléklet; Hevesi 1899; Objectivus 1899.

${ }^{91}$ A terveket például a szakírók csak futtában tudták megnézni, miközben a napilapok zsurnalisztáinak több idejük volt. (VK 5 [1899] 14. 2.) Ez a probléma a Tözsdepalota pályázatának esetében is elökerült. (Komor 1899a.) A kapcsolódó sajtóvisszhangról: Németh-Marótzy 2013.

${ }^{92}$ BH 19 (1899) 9; PH 59 (1899) 8. 5.

${ }^{93}$ Érdekes, hogy csak azután nyitották meg a kiállítást a nagyközönségnek, miután írásban hivatalosan is megszületett a bírálati jegyzőkönyv, miközben tartalmát már közölték. A hírlapírók minden bizonnyal informális úton jutottak hozzá a kéziratos bírálathoz, vagy szóbeli értesülést szereztek.

${ }^{94}$ BTM Kiscell Foerk-hagyaték, 1tsz. nélkül.

${ }^{95}$ Haber 1899; BTM Kiscell Foerk-hagyaték, ltsz. nélkül.

${ }^{96}$ Pálóczi 1899

${ }^{97} \mathrm{P}[$ aur] 1899. 
tővé tette a bírálóbizottsági jegyzőkönyv közölt részeit. Haber arra is kitért, hogy az addig megjelent cikkekben mi volt a központi kérdés: a zsinagógáknak mi legyen a stílusa. ${ }^{98}$ Erről szintén egy, a felekezethez szorosan kötődő periodikában, az Izraelita Magyar Irodalmi Társulat Évkönyvében írt a múvészettörténész Dr. Meller Simon, ${ }^{99}$ aki jártas volt a zsidó liturgiában, de emellett az építészeti formálásról is határozott véleménye volt. ${ }^{100}$ Haberral mindketten tévútnak tartották a mór-arab stílust és a salamoni templomhoz való formai visszatérést. ${ }^{101}$ Erről a kérdésről is szól a Pester Lloyd Objectivus álnevü szerző tollából megjelent cikke, amely miatt parázs vita alakult ki az ismeretlen szerző és a tervpályázat kapcsán érintett kör - azaz a pesti zsidó hitközség és az építészek - között. ${ }^{102}$ A cikk témáját a Magyar Mérnök és Építész Egylet mü- és középítési szakosztálya is napirendre vette, és felháborodásának adott hangot, bár nem a stíluskérdés miatt. ${ }^{103}$ Egy bevallottan laikusnak is szöget ütött a fejébe a zsidó templom építészeti problematikája, és beküldte a Bibliából kimásolt és rövid bevezetővel ellátott szövegrészt az építészek segítségére, amelyben Salamon templomát írták le. ${ }^{104} \mathrm{~A}$ vita lezárása a sajtóban már nem jelent meg, a kérdést valószínűleg nem is lehetett volna ezen az úton megoldani, különösen úgy, hogy a pályázat tárgya nem valósult meg; de jól jellemzi a korszakot - és leginkább a magyar sajtó plurális, konfrontatív jellegét -, hogy egy kifejezetten építészeti probléma megtárgyalása kilépett a szaksajtó közegéből, és laikus hozzászólók is írtak cikkeket a témáról, arra pedig reakciók születtek a szakma részéröl.

A lipótvárosi zsinagóga meg nem valósult épületének pályázata az építészettörténet historiográfiájában is kiemelt fontosságú téma. Ez volt az egyik első pályázat, amelyről részletes, önálló építészettörténeti kutatás jelent meg tervelemzéssel. ${ }^{105}$ A magyar müvészettörténeti kutatásban - ha építészettörténeti a téma - hagyományosan a szöveges források és tervek olvasása adja a gondolatmenet gerincét, és ehhez társul az építés kontextusának történeti kutatása. A kutató főként a korabeli írásos

${ }^{98}$ Haber 1899. 2.

${ }^{99}$ Meller 1900.

${ }^{100}$ Meller Simon (1875-1949) művészettörténész, 1910-1924 között a Szépművészeti Múzeum grafikai osztályának vezetője volt, az itáliai, a német és a magyar művészettel foglalkozott. (Gábor 1998. 14.)

${ }^{101}$ Ennek a jelen tanulmány keretei közt csak szöveghagyományi-publikációs terjedésbeli jelentőségét emeljük ki.

${ }^{102}$ A Pester Lloyd szerkesztősége kiemelte, hogy vitára érdemesnek tartották megjelentetni az írást, de nem feltétlenül értenek egyet a benne írtakkal. (Objectivus 1899.) Az Egyenlöség címü lapban válaszolt Komor Marcell, ott a szerkesztőség megjegyzése Komor cikkéhez az volt, hogy építész szakférfinek tartották Objectivust, mert nem értett a zsidó teológiához és liturgiához. Komor, aki pedig építész, inkább vallási szakértőnek tartotta, mert szerinte Objectivus nem értett az építészethez. (Komor 1899b.)

${ }^{103}$ A magyar építészek problémája - a zsinagóga kialakításának és stílusának kérdése - mellett a német nyelvű Pester Lloyd vendégszerzője azt is felvetette, hogy mivel a magyar építészek képtelenek voltak betartani a költségvetési kereteket, ezért külföldi építésztől kellene beszerezni a tervet, ez természetesen szúrta az egyleti tagok szemét. (Objectivus 1899; ÉPIP 23 [1899] 129.)

${ }^{104}$ Salamon király temploma Budapesten. Magyar Estilap 9 (1899) március 9., 2-3.

${ }^{105}$ Gábor 1998. Természetesen korábban is jelentek meg pályázatokról építészettörténeti kutatások, többen is tárgyalták a Magyar Tudományos Akadémia székházára kiírt versenyt, írásaikban azonban nem a tervek a főszereplők. (Hajnóczi 1988; Kemény 1991.) 
források, különösen jegyzőkönyvek, építészek megjelent szövegeinek logikájának megértésén keresztül próbálja feltérképezni az alkotás folyamatát. Így fordulhat elö, hogy föként müvészettörténészi tanulmányokban élnek tovább a tervleírások, jegyzőkönyvek és kritikák szöveghagyományai.

\section{SZEGED, FOGADALMI TEMPLOM 1903-1904}

A következő példánk helyszíne a mai Magyarország délkeleti régiójának egyik lefontosabb városa, Szeged, ahol Budapest mellett a legnagyobb egybefüggő historizáló épületállomány maradt fenn. Ennek az a szomorú oka, hogy a városban 1879ben óriási károkat okozott az árvíz, így újra fel kellett építeni a város nagy részét. A vész elmúltával a megmenekülést jelentő gyors segítséget isteni gondviselésnek tekintették, és hálájuk jeléül a város képviselőtestülete 1880 novemberének végén fogadalmat tett egy óriási templom építésére. A fogadalom beváltásához Bonnaz Sándor püspök anyagi segítséget nyújtott 1897-ben, ${ }^{106}$ a tervpályázatot azonban csak 1903 novemberében hirdették meg egy 3400 fö befogadására alkalmas templomra. Az Épitészeti Szemle közölte a rövidített programot, az érdeklődőket a városhoz vagy a Magyar Mérnök- és Építész Egylethez irányította további információkért. ${ }^{107}$ Ennél sokkal részletesebb kiírást közölt a Müvészet címü folyóirat, ${ }^{108}$ amely főleg a „modern” irányzatot követö müveknek és eszméknek adott helyet, de volt egy „Lejáró pályázatok" címü rovata is. A kiírás szerint a pályázat bizonyos tekintetben nagyon alaposan volt elökészítve: ugyan nem nevesítve, de közölték, hogy a 12 tagú bírálóbizottságban az Egylet által kijelölt 3 fó építész lesz; megadták, mi fog történni, ha sikertelen a pályázat; megvételre javasolt tervek esetén milyen összeggel gazdálkodhat majd a zsüri. Az Egylet régi követelését is teljesítette a város, miszerint a nyertes szerződésében az Egylet tervezői díjszabása szerint fogják számolni a munkadíjat, amelybe az első díj is beleszámít, még arra is kitértek, hogyan kezelik majd a szerzői jogokat a közlés szempontjából. Mégis, érdekes módon néhány építészeti szempontból igen fontos tétel kimaradt, vagy nem volt világos a kiírásban. A bírálóbizottság az értékelés lezártakor, amikor megállapították, hogy az első díjat nem tudják kiadni - hiszen nem volt olyan terv, amelyet kivitelezésre alkalmasnak találtak -, jegyzökönyvbe vette, hogy ez nem csak a pályázók hibája. A hátráltató tényezők közül a legsúlyosabb talán az volt, hogy a pályázók nem tudták pontosan, hova épülne a templom, és mi lesz a pontos funkciója; ez a szöveg az Építő Ipar első jegyzőkönyvközlő cikkében meg is jelent. ${ }^{109}$ Pedig a körültekintésre már a pályázat előkészítése

${ }^{106}$ Fogadalmi templom. ÉSz 5 (1897) 161.

${ }^{107}$ Szeged. ÉSz 11 (1903) 295.

${ }^{108}$ Lejáró pályázatok. Müvészet 2 (1903) 359.

109 ,a) a programban nem volt megjelölve az épitési telek helye; b) nem határozták meg elöre, hogy a Fogadalmi templom egyúttal parochiális templom is kell, hogy legyen; c) két megnevezett kápolnán kivül a program még hat olyan oltárt is követelt, amelyekhez szervesen tartozó tereket kellett tervezni, és ez a szokatlan követelmény az egészséges alaprajzi megoldást rendkivül megnehezitette." (A szegedi fogadalmi templom pályaterveinek bírálata. ÉPIP 27 [1904] 199.) 
folyamán felhívták a figyelmet: 1903 elején a Magyar Építőművészek Szövetsége egyik ülésén felszólalt Jakab Dezső, hogy a Szövetség idejekorán küldjön hivatalos levelet a városnak, hogy a pályázati kiírás feltétlenül pontos legyen. ${ }^{110}$

Az építés történetében tehát a pályázat ismertetett első fordulója nem volt eredményes szakasz, a második fordulóban és a megvalósulásban is kevés az egyértelmü siker. ${ }^{111}$ Az épület kiemelt jelentőségüvé vált az első világháborút lezáró 1921-es békeszerződés - és az ország területi integritásának megbomlása - után, ami miatt az újjászervezett katolikus egyházmegye központja a püspöki székhely, Szeged lett Temesvár helyett. Hosszú, konfliktusos, és az első világháborúval megszakított folyamat végén avatták fel a templomot 1930-ban. A pályázatot tehát ezen okok miatt a felavatás után íródott építéstörténetekben, beszámolókban alig említik. Már a pályázat lezajlásakor is az eddigi példáinktól merőben eltérö jellegü cikkek születtek: gyakorlatilag csak a jegyzőkönyv vagy annak részletei jelentek meg, önálló értékelés vagy kritika nem. ${ }^{12}$ Még az amúgy mindig egyéni véleményt megjelentető Építészeti Szemlében is egy rövid bevezető után - amelyben különös módon még a későbbi tervező, Foerk Ernő nevét is elírták - csak a jegyzőkönyv részleteivel adtak hírt a pályázatról. ${ }^{113}$ A nagyszámú pályamü azonban ki volt állítva két helyen is, ahogy az már a kiírásban is szerepelt: először természetesen Szegeden 1904. június 12-től két hétig a Kultúrpalotában, majd Budapestre szállították és az Iparmüvészeti Múzeumban volt látható augusztus 11-től két hétig. ${ }^{114}$

Két szakfolyóirat volt, amelyben illusztrálva adtak hírt a pályázatról. Az Építő Iparban a szerkesztőség egyik tagjának szabadkézi rajzaival kísérve jelent meg a szöveg (4. ábra). ${ }^{115} \mathrm{Az}$ eljárás újszerüsége miatt a szerkesztő meg is jegyezte, hogy reméli, elnyeri az olvasók tetszését. Mindenesetre bepillantást enged az utókornak abba, hogy akkoriban hogyan skiccelt egy építész: minden rajzot úgy kezdhetett a szerző, hogy meghúzta a tengelyeket, egyet függőlegesen és egyet-egyet keresztet formázva. Ezek szimmetriatengelyként is müködtek, ha az elválasztott részek ugyanolyanok voltak, nem rajzolták ki mindkét oldalt a mai gyakorlathoz hason-

\footnotetext{
${ }^{110}$ A Magyar Építőművészek Szövetsége jan. 22-i ülése. ÉPIP 26 (1903) 28.

${ }^{111}$ A második, szűkebb körü meghívásos pályázat után sem tudtak egyértelmü nyertest hirdetni; a templomépítő bizottság négy évvel később, 1908-ban inkább az egyik zsüritagot kérte fel a tervek elkészítésére, ami etikai szempontból igencsak problémás. Schulek Frigyes azonban megkezdte a munkát, de végül felmentését kérte idős korára hivatkozva 1912-ben. Ekkor a már nyolc éve lezajlott pályázat harmadik díjas müvének egyik tervezőjét, Foerk Ernőt kérték fel. Az épület történetéről és müvészettörténeti hátteréről Szőnyi Ottó írt kiváló tanulmányt. (Szőnyi 1932.) A Magyar Iparmüvészet ezen egész lapszáma a templommal foglalkozott, a két világháború magyar kultúrpolitikájának legfontosabb személye, Klebersberg Kuno is írt egy cikket az identitáspolitikailag kiemelt projektről. (Klebelsberg 1932.)

${ }^{112} \mathrm{Az}$ Épitő Ipar mellett a helyi napilapban, a Szeged és Vidéke című újságban is csak az eredményről olvashatunk. (A fogadalmi templom-pályázat eredménye. Szeged és Vidéke 2 [1904] június 12., 7-8.)

${ }^{113}$ A szegedi fogadalmi templom. ÉSz 13 (1904) 178-179.

${ }^{114}$ A helyi cikkben a budapesti kiállítás Szeged város polgármesterének javaslataként tünik fel, de valószínűleg csak a helyszín lehetett a polgármester kérése. Az elhelyezéshez a Magyar Mérnök és Építész Egylet segítségét kérték, és az újság epésen megjegyezte, hogy ha már drága pénzen megvette a város a terveket, legalább mutogassa. (A fogadalmi templom pályatervei. Szeged és Vidéke 2 [1904] július 29., 5.

${ }^{115}$ A szegedi fogadalmi templom pályaterveinek bírálata. ÉPIP 27 (1904) 199, 207, 213, 219, 225, $231,239$.
} 
lóan. Azonban ha elégedetlenek is lettek volna az olvasók az ilyesféle rajzi közvetítéssel, a pályázat kiírásának évében indult egy folyóirat, amely némileg a segítségükre sietett: az önállóan igen rövid életủ Magyar Pályázatok is közölt terveket (4. ábra). ${ }^{116}$ Így a második díjat elnyert páros, Aigner Sándor és Rainer Károly (,Pax”), a harmadik díjas Foerk Ernő és Sándy Gyula (,Dicsértessék”) páros terveit is ismerjük publikációban megjelent mechanikus másolatban és nem valaki másnak a rajza alapján. Ezeken kívül összesen nyolc tervet ajánlottak megvételre a díjazásra biztosított keretből, ezek közül a harmadik díjról éppen lecsúszott „I. N. R. I.” jeligéset nem ismerjük, csak az Ybl Lajos által tervezett „Patrona Hungariae” és az Aigner-Rainer páros alternatív, „Dom” jeligés pályatervét. A harmadik díjat kapott Foerk-Sándy duó alternatív tervét (,,Szebb lesz”) is meg tudta jelentetni a lap. Ezeken kívül Hickisch Rezső (,,Ruskin”) és Schoditsch Lajos (,,5/8”) terveit ismerjük; valamint Goll Elemér dicséretet nyert pályamủvének három lapját, ami 1905ben az Ország-Világ címủ képes családi lapban ismertetés és jelige nélkül jelent meg. ${ }^{117}$ A Magyar Pályázatok profilja szerint csak hivatalos szöveget mellékelt a tervekhez, általában a bírálati jegyzőkönyvet. A szegedi jegyzőkönyvből nyolc terv bírálatát ismertették, ezek közé egy olyan is került, amelynek viszont nem jelentették meg a tervanyagát (,,Hit”). A jegyzőkönyvet szerzö bírálóbizottságnak az Egylet által delegált tagjai nagyrészt itt is egyetemi tanárok voltak: Czigler Győző, Schulek Frigyes, rajtuk kívül pedig Fittler Kamill, az Országos Iparmüvészeti Múzeum igazgatója, aki a két tanárhoz hasonlóan gyakorlott bíráló és szakíró volt. ${ }^{118} \mathrm{~A}$ teljes jegyzőkönyv - a nagy érdeklődésre való tekintettel - megjelent az Épitö Ipar hasábjain. ${ }^{119} \mathrm{Az}$ írásban könnyen felfedezhetőek a bírálati szempontok, kifejtésük sorrendje is viszonylag kötött: először a pályázati kiírásnak való megfelelést állapították meg, sokszor kiemelve a kórus méretét; aztán az alaprajzi elrendezést, az ebből következő épületrészeket és -használatot, majd a külső és belső formai kialakítást, szerkezeteket ítélték meg. A kialakításnak a pályázati elöírásban foglalt emlékszerüségnek is meg kellett felelnie, így ezt többnyire külön említették. Ez a szempontrendszer eléggé hasonlít a Fazekas téri református templom jegyzőkönyvének szerkezetére, és a helyzet is hasonló volt, hiszen itt is a templomépítő bizottság laikus tagjainak készült a jegyzőkönyv, azoknak, akik a végleges itéletet meghozták. Azonban az a jegyzőkönyv összeszedettebb és egységesebb, nyilvánvalóan a sokkal kevesebb terv leírása és értékelése rövidebb ideig tartott, és kevesebb teret engedett a következetlenségeknek.

${ }^{116}$ 1907-től, az ötödik évfolyamtól kezdve a lapban közölt magyarázat nélkül Magyar Épitőmüvészet néven jelent meg. A Magyar Építőmúvészek Szövetségének lapja lett, szünetekkel és névváltoztatásokkal a mai napig müködik.

${ }^{117}$ Oldalnézet, homlokzat, hátsó nézet. (OV 26 [1905] 194.)

${ }^{118}$ Alpár Ignác a róla írt nekrológban külön kiemeli, hogy nagy képzettségü, igazságos és elfogulatlan bírát veszített a müvészeti élet. (Alpár 1910.)

${ }^{119}$ A szegedi fogadalmi templom pályaterveinek bírálata. ÉPIP 27 (1904) 199-202, 207-209, 213-215, 219-220, 225-226, 231-233, 239-240. 
A nyilvánossá tett és a pályázóknak is a visszaadott tervek mellé csatolt szegedi jegyzőkönyv szóhasználata eltér az Épitő Ipar vagy más szakfolyóirat megszokott szakkifejezéseitől és szófordulataitól, amely arra enged következtetni, hogy nem az ezekben a szaklapokban rendszeresen publikáló szakíró állította össze a szöveget, valószínúleg jegyzetek alapján. Vannak esetek, amikor kissé mintha ellentmondanának egymásnak a stílussal kapcsolatos kifejezések; például rendszeres jelző a román vagy a gót stílus „,modern fölfogásban”, azonban egy helyütt a tervleírásban szereplö „,modern román” kifejezést idézőjelek közt, zárójelbe tett kérdőjellel olvashatjuk, mutatva, hogy a szövegező szerint ez így értelmetlen. ${ }^{120}$ Az építészeti formálás megítélésében a modernnek nevezett megközelítést egyértelmüen nem ítélik el, csak enyhe távolságtartást árul el a szöveg. ${ }^{121}$ A stílusok megnevezései pontosító elö- és utótagok (például ,,proto-román” vagy „,...modern felfogásban”) nélkül sem egységesek, különösen a gótikát nevezik többféleképpen: a szövegben előfordul az ekkor már köznyelvi megnevezésnek számító csúcsíves stílus, ${ }^{122}$ de a ma használatos neogótika is. ${ }^{123} \mathrm{Az}$ eredmény indoklása sem egységes, van, amikor csak egy resolute megállapítás, ${ }^{124}$ de van, amikor bővebb magyarázat is társul hozzá. ${ }^{125}$ Egy helyütt az 1899-es, lipótvárosi zsinagóga terveit elemző H. Gaal Adorján írásában olvasható térhatásleírást - mely szerint képzeletben a tervezett épületben áll - is túlszárnyalja a bírálat azzal, hogy nemcsak benne áll a tervezett épületben, hanem azt mozgásban is látja. Leírja, hogy a feltárulással együtt milyen lesz a térhatás: „, a hatásnak nyomatékát a magas hajók keresztezö helyén kifejlesztett terjedelmes kupolára helyezi, amelynek térhatását elökésziti mind a 4 keresztág felöl a közép felé emelkedö kolostorboltozatokkal." ${ }^{26} \mathrm{H}$. Gaal elemzéséhez hasonlóan - de erösebben - itt is megjelenik, hogy a szerző megpróbálja kitalálni, hogy a tervezés során mit gondolhatott az alkotó: „Amit a tervező az alaprajzban csak sejtet, azt fölépitésében kifejezésre is juttatja, hogy t. i. szemei elött egy nagy katedrálisnak a megvalósítása lebegett, amelyet azonban az adott viszonyokhoz mérten csak sokkal szerényebb keretben, lényegesen kisebbitett méretekben van alkalma megvalósitani." ${ }^{127}$ A századforduló idején feltünt általános jelenség itt is érezhetö; bizonyos esetekben értékelik a tervek rajzi minőségét is. Egy alkalommal ez a tanáros kritika tompítása, az illető szorgalmát dicsérik a sok, szép kiállítású rajz és a részletes tervleírás miatt. ${ }^{128}$ Inkább negatív

\footnotetext{
${ }^{120}$ I. m. 226.

${ }^{121}$ „A tornyok harangházának alakitása bár bizarr, de érdekes. Az architektúra stylusa modern felfogású román, egyéb reminiscentiákkal párosultan.” (I. m. 209.)

${ }^{122}$ I. m. 220.

${ }^{123}$ I. m. 214.

${ }^{124}$ „Két mellékoltára nem célszerü és négy hiányzik.” (I. m. 226.)

${ }^{125}$ „A belsö térhatásnak koronázó részét képező kupola érvényesülése csorbát szenved az azt tartó 4 boltöv megkettöztetése miatt, amelyek éppen ennek következtében (t. i. a megkettöztetés következtében) a magas hajók többi boltozatánál alacsonyabbnak mutatkoznak.” (I. m. 231.)

${ }^{126}$ I. m. 231.

${ }^{127}$ I. m. 226.

${ }^{128}$ A lényeg valószínűleg az lehetett, hogy az illető nem tudott szerves kapcsolatot teremteni a felhasznált sok homlokzati motívum között. (I. m. 225.)
} 

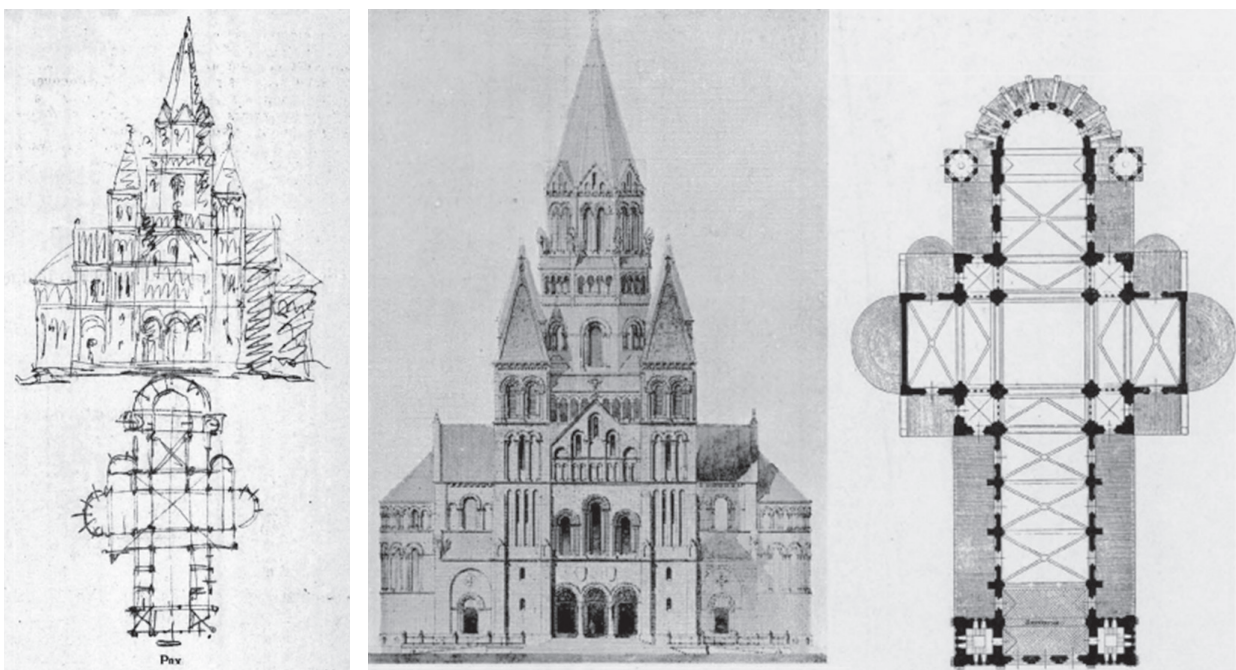

4. ábra. Fogadalmi templom, az Aigner-Rainer páros „Pax” jeligéjü pályatervéről készült vázlat és másolat (ÉPIP 27 [1904] 239; MP 2 [1904] 6.)

kritikaként tủnik fel egy másik dicséret, amely a terv rajzi megoldását illeti: a bírálók szerint minden bizonnyal a terv esszenciája volt az építendő szerkezet ismertetése, és ebben zavaró, ha az amúgy nagyon harmonikusan ábrázolt árnyékolás eltakarja az épületrészek egymáshoz való viszonyait. ${ }^{129}$

A századfordulót követő pár évben a mindennapi gyakorlatban megjelent a vasbeton, bár megítélése még vegyes volt. A szegedi Fogadalmi templom esetében pozitív tényezőként tünik fel, hogy az egyik terv értékelésében a bírálók úgy ítélték meg, hogy könnyeddé tette volna a szerkezetet. ${ }^{130}$ Nemcsak a magukat progresszív, modern építészeknek tartó, általában a szecessziós vagy szecessziós elemeket használó stílusban tervezők nyúltak ehhez az eszközhöz, hanem a történeti stílusokat használó építészek is, ami azt jelzi, hogy összességében 1904-re sokkal változatosabb lett az építészeti eszköztár, mint akár tíz évvel azelött volt. Szintén a századforduló környékén beálló változásként tekinthetünk arra is, hogy a pályázó építészek közül többen nem hagyományos vagy megszokott alaprajzi formálást alkalmaztak, amelyet egy esetben túl profánnak ítéltek a bírák. ${ }^{131}$ Több esetben pedig amiatt kritizálták a tervet, hogy nem az általános római katolikus liturgiának megfelelő a kiképzés, hanem más felekezet liturgiájának felel meg jobban. Kettőt inkább az izraelitákénak tartottak volna alkalmasnak, mert a nők a karzaton kapnak helyet a zsinagógában, egy pedig a protestáns liturgiának felelt volna meg centrális elrendezése miatt. ${ }^{132}$ Ennek több

${ }^{129}$ I. m. 215.

${ }^{130}$ „Trinitas” jeligés tervnél. (I. m. 231.)

131 „Segment” jeligéjü terv. (I. m. 209.)

${ }^{132}$ „In perpetuam Dei memoriam” és ,,Sion” jeligéjü tervek inkább az izraelita liturgiának feleltek meg a szerzők szerint. A „,Centrális” jeligéjü a beszédközpontú liturgiához alkalmazott formája miatt inkább a protestáns vallások számára lehetett volna megfelelő. (I. m. 199, 208, 219.) 
oka is lehet, egyszerủ készületlenség a pályázók részéröl vagy pedig túlságos hagyománytisztelet a bírák oldaláról, akik bizonyos feladatokhoz az egyszer már bevált megoldást tartották üdvösnek. Ez lehetett akár egy alig pár éve megtalált megoldás, amilyenek Schulek Frigyes és Petz Samu eddigre elterjedt centrális ideáltervei voltak, amelyeket a Fazekas téri református templommal kapcsolatban mutattunk be. A téri elrendezés sokfélesége mellett a külső architektúra konvencionális, a legtöbb terv a középkori stílusokhoz nyúl, csak néhány építész választott klasszikusabb megközelítést. ${ }^{133} \mathrm{~A}$ századfordulós új stílusirányzatok itt háttérbe szorultak.

A szegedi Fogadalmi templom pályázatának időszakára úgy tủnik, a korszak jellegzetességei tapasztalattá váltak, ez megjelenik a jegyzökönyvben is: a tervek kiállítása, rajzstílusa változatossá vált, a tervek bírálatában már a tervezési folyamatokat is elkezdték leírni, a térhatás és a feltárulás közbeni térhatás is megjelent a szövegben. Közben az építészeti stílusok keveredése és az egyes felekezetekre jellemző, a liturgiából következő építészeti formálás már nem olyan következetes - sem a terveken, sem a róluk szóló szövegekben -, mint a szigorú historizmusban volt.

\section{BUDAPEST, FERENC JÓZSEF JUBILEUMI TEMPLOM 1913-1914}

Utolsó példánk egy korszak végét jelzi. Az első világháború előestéjén meghirdetett pályázatot Budapest egyik külső kerületének - a Józsefvárosban fővárosi megbízásból felépült tisztviselőtelepnek - római katolikus templomára írták ki 1913 júniusában. A templom pályamüveinek bírálata és az eredményhirdetés már abban az évben zajlott, amelyben ősszel kitört az első világháború, az év végére pedig a világ alapvetően megváltozott. A templom csak 1931-ben épült meg egy újabb pályázaton beszerzett tervek alapján. ${ }^{134}$ De nem csak emiatt más ez a pályázat, sok változást figyelhetünk meg az előző, tíz évvel ezelötti példánkhoz képest. A vizsgálat szempontjából a legfontosabb, hogy teljesen más hangvételü publikációk születtek a templom pályázatáról, mint eddig. Ennek több oka is van: egy aprónak tünő dolog hatását említjük először: az Épitő Ipar azon szokásáról van szó, hogy a pályázati hirdetményeket folyószövegben jelentették meg 1903-tól, amely a határidő után ugyan mindig a hirdető megnevezésével kezdődött, de ebből nem mindig derült ki pontosan a megbízó szervezet. Így volt ez a jubileumi templom esetében is, amelynél csak annyit írtak, ${ }^{135}$ hogy a Ferenc József jubileumi templombizottság a megbízó, de az nem volt egyértelmü, hogy ez egy alapítványi, egyházi szervezet, ami Budapest egyik külső kerületében, Józsefvárosban élő tisztviselőtelepi lakosok közösségéből alakult; az állami egyházszervezethez vagy állami szereplőhöz nem volt köze. ${ }^{136} \mathrm{~A}$ bizonytalan-

\footnotetext{
${ }^{133} \mathrm{Az}$ Aigner-Rainer páros érdekes módon kétféle - romanizáló és klasszicizáló - tervet is benyújtott „Pax” és „Dom” jeligékkel.

${ }^{134} \mathrm{~A}$ templom építéstörténetéröl részletesen: Baku 2018. 61-63, 136-138.

${ }^{135}$ Tervpályázatok. ÉPIP 36 (1913) 279.

${ }^{136}$ Védnöknek magas egyházi tisztséget viselőket és a Habsburg-család előkelő tagjait nyerték meg, elérték, hogy a fővárostól ingyen kapjanak építési telket, ez a múködés hivatalos kötődésủ szervezet látszatát kelthette. (Pap-Pruzsinszky 2000.)
} 
ságot erősítette a bírálók személyének megnevezése. Ahogy ez is viszonylag sokszor előfordult, a Magyar Mérnök- és Építész Egylethez fordult a templomépítő bizottság szakértő bírálók felkérésére. A tagok személyét az Egylet mindig egy bizottsági ülésen döntötte el, amely napirendi pontként bekerült az Építö Ipar hivatalos közleményeibe, majd az egyes pályázati lépésekről is általában röviden hírt adtak. Ezek közül az egyik volt a végleges bírálóbizottság névsorának közlése, amikor beérkeztek a pályamüvek is ${ }^{137} \mathrm{Ez}$ jelen példa esetében több építészt megvezetett, és vitát generált. ${ }^{138}$ Ugyanis azok, akik csak ezt a hírt olvasták, azt gondolták, hogy a személyi egyezés miatt az akkori magyar örökségvédelmi szervezet, a Mủemlékek Országos Bizottsága az építtető, mert a szervezet elnöke, báró Forster Gyula volt a pályázat bírálóbizottságának az elnöke is. Ezt a képzetet az sem gyengítette, hogy tag volt még Budapest főpolgármestere és a fővárosi önkormányzat több tagja, de az Egylet és a Magyar Építőmüvészek Szövetsége, valamint a Müegyetem is delegált tagot. Ugyan a program nem volt nyilvános, de az eredményhirdetés közzététele ${ }^{139}$ után az Épitö Ipar - Épitö Müvészet következő számában megjelent véleménycikk ${ }^{140}$ az egész pályázatot arra a tévútra terelte, hogy a múemlékekkel foglalkozó bizottság templomot építtet és a középkori müemlékek iránti elkötelezettsége miatt a pályázóknak kötelezően előírja a román stílust. Ez 1914-ben már teljesen anakronisztikus elvárás lett volna, a stíluskérdés az egész szakmai diszkussziót uralni kezdte: az Épitő Ipar szerzője és Komor Marcell, a Vállalkozók Lapja címü újságban kritizálták a megbízókat, hogy nem hagynak teret a modern építészetnek, és nemtetszésüket fejezték ki, hogy a Mủemlékek Országos Bizottsága megbízóként lép fel. ${ }^{141}$ Az Épitő Ipar szerzője a résztvevőket is kritizálta, Komor csak müvészileg érdektelennek látta a terveket - egy kivétellel, az első díjjal kitüntetett terv szerzője Lechner Ödön volt, aki Komor szerint megmentette az egész pályázatot azzal, hogy a történeti stílusban való tervezésből is modern és saját stílusának megfelelő tervet készített. Az Építő Iparban még egy válaszcikk is született az első véleményre, ${ }^{142}$ amikor helyreigazítást közöltek, ${ }^{143}$ hogy a Múemlékek Országos Bizottságának semmi köze a pályázathoz, és még kevésbé a stílus kikötéséhez. ${ }^{14}$ Erről a vitáról a napilapokban csak a lechneri magyaros stílus vonatkozásában írtak a mestert támogatva, azokban az esetekben is, ha a kiállítást látogatták és az egész tervfelhozatalról írtak. Az építészeti leírások tekintetében - ahol szerepelt ilyen - azonban a napisajtó szövegei fejlődtek, már nincsenek a szövegekben feltünő tévedések. ${ }^{145}$

\footnotetext{
${ }^{137}$ A budapesti I. Ferenc József-templom tervpályázata. ÉPIP 37 (1914) 47.

${ }^{138}$ Dór 1914.

${ }^{139}$ Tervpályázati eredmény. ÉPIP 37 (1914) 69.

${ }^{140}$ Dór 1914.

${ }^{141}$ Ezrey 1914.

${ }^{142}$ Magyar 1914.

${ }^{143}$ Tévedés. ÉPIP 37 (1914) 111.

${ }^{144}$ A pályázók, talán nem függetlenül a kötött stílustól, legtöbben háromhajós, két homlokzati tornyos, négyezeti tornyos megoldást választottak, kevés a bátrabb, centrális megoldás és a nagyvonalú homlokzat-

${ }^{145}$ Mủépítők vetélkedése. A Ferenc József jubileumi templom tervei. PN 63 (1914) február 17., 5-6; D.I. 1914.
} formálás. 
Az Épitó Iparban még a helyreigazítás elött közölték Csányi Károly hosszabb, az első négy díjazott tervet is közlő elemzését a pályatervekről. ${ }^{146}$ Megemlítette, hogy a kihirdetéskor is vitákat szült az a programpont, amely előírta a román stílust; Csányi megpróbálta indokolni a kikötést. A Müvészet címủ folyóiratban megjelent cikk ismeretlen szerzője nem a pályázatról magáról írt, ${ }^{147}$ hanem Lechner Ödön két müvéről, és visszatért az Épitö Ipar első kritikájára, ${ }^{148}$ hogy miért is nem adta fel Lechner az elveit a kikötött stílus kedvéért. A szövegben csak és kizárólag a stíluskérdésről van szó, viszont a román kori építészeti alkotások megszületésének módját is tudni véli a szerző. ${ }^{149}$ Ez a két írás azt a tíz éve jelen lévő folyamatot illusztrálja, amikor a tervekről úgy írnak, mintha a szöveg szerzőjének közvetlen belátása lenne a tervezői folyamokba. Ez azzal egészült ki, hogy a szerzők egyrészt a bírálóbizottság szándékait, ${ }^{150}$ másrészt a korábbi korok építőinek gyakorlatát is leírták, hol feltételezve, hol kijelentő módban. Ennek a megközelítésnek másik formájában a kritikus már nemcsak a meglévő tervanyagot értékelte, hanem azt is kifejtette, hogyan lett volna jobb a terv: Csányi a jegyzőkönyv bírálati részeit is idézte bizonyos esetekben, többek közt azt a részt, amelyben a nyertes tervröl azt írták, hogy milyen javaslatuk lenne a terv javítására. A Katolikus Szemle ismeretlen szerzője is pont úgy gondolta, ha Lechner tervén a tornyok szervesebben csatlakoznának a központi épülethez, csak nyerne vele a kompozíció, bár megdicsérte, és mesternek nevezte Lechner Ödönt. ${ }^{151}$ Nem tudjuk, hogy a vélhetően laikus publicista a jegyzőkönyvből vette ezt a gondolatot, vagy önálló megfigyelés és javaslattétel volt a megjegyzés - de érdekes mindenesetre, hogy az egész építészeti szekcióból csak ezt és így emelte ki a beszámolóban. Más tervezők terveinél ez nem merült fel, csak Lechnernél, de jelez egy tendenciát, amely ma is elö-előfordul: a bíráló nem bírál, hanem elkezd maga tervezni.

A publikált szövegeknek van még egy tartalmi aspektusuk, amely az eddigi példáink esetében nem volt tapasztalható: a tervek száraz ismertetését, építészeti szempontú értelmezését és a véleményezést egyre inkább kettéválasztják. Az eddig is jellemző volt az eseteinkre, hogy azelőtt mondtak értékítéletet a tervekről, mielőtt a hivatalos közlemények megjelentek volna - de ez inkább a napi sajtó ismérve volt. De önálló javaslat, vagy véleménycikk - amilyet a lipótvárosi zsinagóga esetében például az Objectivus néven publikáló szerző írt - már csak a bírálat után jelent

${ }^{146}$ Csányi 1914.

${ }^{147}$ rp 1914. 627.

${ }^{148}$ Dór 1914.

${ }^{149}$ „A román stílusnak ez a periódusa még telve volt népies elemekkel. A vezetö agy kompozíciója csak a keret volt, amelyben az építő munkások a maguk izlésük és tudásuk szerint faragták a részleteket. És ez, úgy látszik, m é g külön szeretettel vonzotta Lechnert ezen stílushoz” (rp 1914. 100).

${ }^{150}$ Csányi 1914. 83.

${ }^{151}$ „A román-bizánci stílusok hagyományaiból kiindulva azonban most is eredeti alkotást hozott létre, amelyen különösen a régi formáknak a vasbetonszerkezettel való összeegyeztetése sikerült. Ha a tornyokat a centrális kupolaépitmény testével szorosabb kapcsolatba hozná s arányaikat a kupoláéval határozottabban összehangolná, terve kivitele esetén egyöntetüség és monumentalitás tekintetében csak nyerne. A Ferencz József jubileumi templom mindenesetre a székesföváros legkiválóbb monumentális épületeinek egyike lesz, ha Lechner tervei alapján valósitják meg." (x. 1914. 627.) 

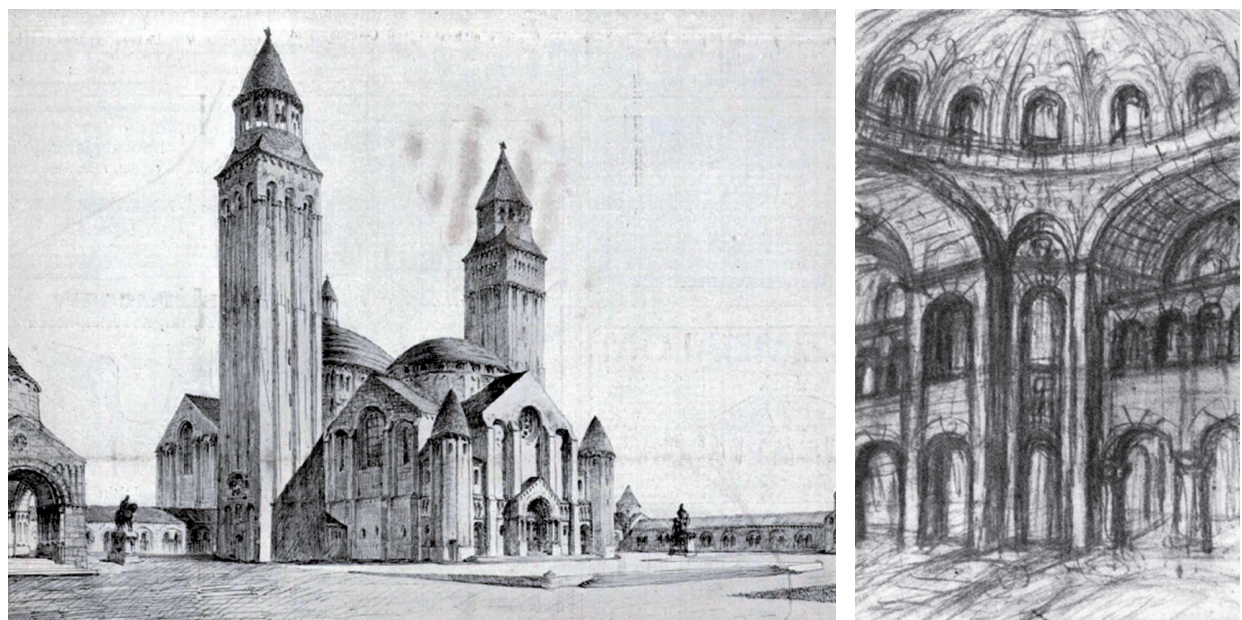

5. ábra. Ferenc József jubileumi templom, Lechner Ödön pályatervének távlati képe (megjelent VU 61 [1914] 275; ÉPIP 28 [1914] 83; MÉ 12 [1914] 3; Müvészet 12 [1914] 19) és vázlat a belsőről (Müvészet 12 [1914] 101)

meg. ${ }^{152}$ A Fogadalmi templom esetében egy figyelmetlenséget is tartalmazó, mondhatni vádaskodó véleménycikk - olyan címmel, amelyből egy egyszerü beszámolóra is lehet következtetni - hamarabb jelent meg, mint a pályázat klasszikusabb leíró-értelmező jellegü értékelése. ${ }^{153} \mathrm{Az}$ ilyen szövegekben megjelenő leírások hangulata és megfogalmazása is sokat változott, sokkal inkább történetmesélő jellegük van, ahol a szerző véleménye hangsúlyosabban megjelenik - hol a pikírt, ironikus hangnemben, ${ }^{154}$ hol a rajongás, vagy személyes történetek vonalán, mint egy anekdota, ahogy a szerző saját kisfiával sétálva viccelődik. ${ }^{155}$ De a jelzők és hasonlatok is változtak, egyrészt minden cikkben érezhetően megszaporodtak a konkrét történelmi példák előképekként való említései; másrészt ezek olykor hangulatfestő jelzőkkel vannak kiegészítve, ahogy Magyar Vilmosnál: a kora olasz és román gótikában „,Aquitania borongós misticismusa ölelkezik Lombardia izzó mosolyával" ${ }^{156}$ A szikárabb építészeti leírások is képletesek, ami nem újdonság, hiszen a jegyzőkönyvekben találkoztunk már ilyennel a Fazekas téri református és a szegedi Fogadalmi templom esetében; ezek laikusoknak készülő hivatalos okiratok voltak. A szakfolyóiratokban eddig a bevett módszer az volt, hogy az építészeti elem elhelyezését, térhatását, feltárulását és némileg a végleges használatot írta le a szakíró. Csányi Károly cikkében összekapcsolja ezeket a részeket: a tervezői gondolattól folyamatában jut a végső felhasználásig. A közlekedési útvonal példáját nézve; az elmúlt évtizedekben ezt általában

\footnotetext{
${ }^{152}$ Objectivus 1899.

${ }^{153}$ A szegedi fogadalmi templom. ÉSz 13 (1904) 178-179.

${ }^{154}$ Dór 1914.

${ }^{155}$ Ezrey 1914.

${ }^{156}$ Magyar 1914. 96.
} 
a szükös vagy tágas jelzőkkel látták el, szikáran vizsgálták, hogy az istentiszteletet zavarná-e a használata. Csányi erről így ír: „A közlekedésre a tervező kiváló gondot forditott: kilenc tágas és jól elhelyezett ajtón vezeti ki a közönséget." 157

Az Építö Ipar, a Müvészet, de még a Katolikus Szemle szerzöi is mind tervezöi szerepből mondtak ítéletet, miközben szakírói íráskészségük érezhetően irodalmibbá vált a korábbiakhoz képest. Részben megtartották a kialakult gyakorlatot és rögzült szöveghagyományokat is: a leírást többnyire az alaprajzzal és az abból kifejlődő épülettömegekkel kezdték, majd az arányokat, külső és belső térhatást említették. A festői, művészi hatást vagy a liturgiának való megfelelést is sorra vették, és példáink közül először a szakértői zsürivel is vitába szálltak. ${ }^{158}$ A bírálók ítélete önállóan nem jelent meg publikációban, ${ }^{159}$ a Magyar Épitömüvészetben a pályázat hivatalos jegyzőkönyvének csak azon részletei kaptak helyet, amelyek a pályázatnak való megfelelést és a költségvetést érintették. A pár oldalas, adatokban gazdag és valóban nagyon objektív szöveg mellett az összes díjazott vagy megdicsért terv is megjelent. ${ }^{160}$ Itt is a távlati képeket preferálták és az alaprajzok többször a távlat sarkában, alig kivehetően vannak beszerkesztve. A másolat minősége sem egységes, van, amelyik vélhetően fotó, gyürődések vagy alapszürkeség látszik rajtuk, több pedig kontrasztos és éles kontúrú másolat.

Ami az illusztrációkat illeti, itt is több pontban változást regisztrálhatunk: az első ábrákkal kísért cikk Csányi Károlyé, amelyben nemcsak utal tervekre, de azok olyan sorrendben vannak elhelyezve, ahogy szó esik róluk, a cikket pedig azzal zárja, hogy a mellékelt nagyméretü, részletes és szemléletes képek bővebb felvilágosítást nyújtanak a kedves olvasónak. A nagyobb méretủ képek már nem ortogonális nézetek, hanem látványosabb távlati képek a szakfolyóiratokban is. A Müvészetben megjelent cikk - amely nem a pályázatról magáról szólt, hanem Lechner Ödön két művéről ${ }^{161}$ nemcsak Lechner pályamüvének összes tervlapját mutatta be nagyon jó minőségben, hanem a hozzá tartozó vázlatokat is úgy, hogy a szövegben sem alaprajzi értékelés, sem a funkciók bemutatása, sem a tömegformálás elemzése nem jelenik meg (5. ábra). Még egy illusztrált sajtómegjelenésről tudunk, azonban ez olyan, mint a szegedi Fogadalmi templom Vasárnapi Ujságban megjelent Gollterve: sajnos semmilyen információt nem közöltek Lechner Ödön nyertes tervének távlati képéhez. ${ }^{162}$

\footnotetext{
${ }^{157}$ Csányi 1914. 87.

${ }^{158}$ Csányi az írásban többször reflektál a bírálóbizottsági jegyzőkönyvre, egyetért vagy vitatkozik véleményükkel. (Csányi 1914. 87.)

${ }^{159}$ A fővárosi levéltárban elérhető a teljes szöveg, amely az előző, már ismertetett példák szerkezetét követi. (Tisztviselő telepi templom, I. Ferenc József emléktemplom, 1914-es pályázati jegyzőkönyv BFL XV.17.d.328 - KT T 24)

${ }^{160}$ A Rezső-téri templom tervpályázata. MÉ 12 (1914) 1-16, 31, 83-87.

${ }^{161} \mathrm{rp} 1914$.

${ }^{162}$ Lechner Ödön első díjat nyert pályaterve a tisztviselő-telepre tervezett Ferencz József jubileumi templomhoz. $V U 61$ (1914) 275.
} 


\section{ÖSSZEGZÉS}

Az építészeti tervpályázatok esetében nem mindig maradt fenn a tervanyag, vagy valósult meg az épület, így az építészettörténésznek sokszor korabeli szövegeket kell vizsgálnia, és azokból kell következtetéseket levonnia. A tervek helyes olvasásán túl a pályázatok egyéb forrásainak feltárása közelebb vihet az adott kor építészetről való gondolkodásához. Ha értjük a historizmus szerzőinek prioritásait, ismerjük a leírások stílusának alakulását, értelmezhetjük is a szövegeket. Az elemzett példák nyomán kirajzolódott, hogy a pályázatok bírálói a kiírásnak és alapvető építészeti elvárásoknak való megfelelés vizsgálata mellett a megbízó igényeihez igazodva szövegezték értékelésüket. Ez különösen akkor szembetűnő, amikor a döntést nem bízták rájuk, csak annak meghozásához kérték szakértő segítségüket. Ilyenkor nagyon ügyeltek rá, hogy a laikus közönségnek is érthetö legyen, hogy melyik tervet értékelik jobbra és miért. A szaknyelv stílusterminusai az 1890-es évekre megszilárdultak, a napi- és családi lapok kritikáiba és ismertetéseibe az új századtól fokozatosan beszivárogtak, és az építészeti témák egyre nagyobb teret hódítottak a nem szakértői közönségnek szóló sajtóban. Látjuk, hogyan generált vitát egy épülettípus megalkotása, hogy mit tartottak jó építészetnek, mi számított hibának, és mi jelent meg ebből a sajtó által leképezett közbeszédben. Bár a korszakban a stíluspreferenciák változtak, értékelték a választott építészeti megközelítés koherens formai - téri, tömegformálási, részletképzési - alkalmazását és ettől függetlenül hangsúlyosan a funkcionális megfelelöséget. A szakírók egyre inkább figyeltek a tervezéselmélet kérdéskörére, példáinkban az elméleti megközelítés - és a már kiérleltnek tekintett ideális megoldások alkalmazása pedig elvárásként - a szegedi esetben a bírálatokban is megjelent. Áttekintett példáink nyomán végigkövettük a bírálóbizottsági értékelések és véleménycikkek stílusának változását a tényszerü, esetleg magyarázó leírásoktól, a tervezői nézőpontú elemzésig, személyesebb hangú véleménycikkekig. Határozott fejlődési ívet járt be, ahogy a tervekből összeállítható mentális térösszerakási képességet kezelték a szövegek. Kezdetben teljesen természetesnek vették ezt az építészi készséget, a szövegek nem is érintették a témát, majd egyre tudatosabban jelent meg a szövegekben. A korszak végére már olyan elemekről írtak, amelyek a kész épületben mozgás közbeni feltárulással lehettek volna csak megfigyelhetők. Ez részben a laikusok felé tett gesztus volt, hogy értsék és átlássák a speciális tudás nélkül nehezen olvasható terveket, részben azt is jelzi, hogy ez a gondolkodásmód sokkal tudatosabbá vált a tervezésben is, amelyről előszeretettel írtak a szakírók. Az illusztrációk megjelentetésének technikai és financiális egyszerüsödése nyomán a sajtóban megjelent tervek mennyisége megnött, a szöveg és kép kapcsolata a leírásokban szorosabbá vált. A szaksajtó fejlődését figyelhetjük meg abban, hogy lett igény / kereslet olyan lapokra, mint a Magyar Pályázatok címủ speciális kiadvány, amelyben a tervek, fotók vették át a föszerepet. 


\section{IRODALOM}
[n. n.]
[n. n.]
[n. n.]
[n. n.]
[n. n.]
[n. n.]
[n. n.]
[n. n.]
[n. n.]
[n. n.]

Alpár 1910

Baku 2018

Csányi 1914

Czigler-Steindl-Ybl 1884

D.I. 1914

Dercsényi 1999

Dór 1914

Ezrey 1914

Fülep 1918

Gábor 1998

H. Gaal 1899

Haber 1899

Hajnóczi 1988

Hevesi 1899

Hoss 1948

J.L. 1893

K.Á. 1896

Kapitány-Horváth 2011
A kaposvári plébániatemplom ügyében. EL 4 (1884) 52-57.

A budai református templom. Buda és Vidéke 2 (1893) 20. 8-9.

Der neue Calvinerkirche in Budapest. Der Architekt 3 (1897) 5-6.

A Lipótvárosban építendő új templom pályázati programmja. Egyenlőség 12 (1898) 8. 12-13.

Concurrenzpläne für die Synagoge in der Leopoldstadt in Budapest. Der Architekt 5 (1899) 26-27, 30-31, 39-40.

Salamon király temploma Budapesten. Magyar Estilap 9 (1899) március 9., $2-3$.

A szegedi fogadalmi templom. ÉSz 13 (1904) 178-179.

A szegedi fogadalmi templom pályaterveinek bírálata. ÉPIP 27 (1904) 199-202, 207-209, 213-215, 219-220, 225-226, 231-233, 239-240.

Müépítők vetélkedése. A Ferenc József jubileumi templom tervei. PN 63 (1914) február 17., 5-6.

A Rezső-téri templom tervpályázata. MÉ 12 (1914) 1-16, 31, 83-87.

Alpár Ignác: Fittler Kamill. MMÉEHÉ 29 (1910) 289.

Baku Eszter: Hagyomány és újitás - A centralitás történeti hagyománya és korszerüsége a két világháború közötti magyar templomépitészetben. $\mathrm{PhD}-$ értekezés. Kézirat. 2018.

Csányi Károly: A Ferenc-József-jubileumi templom pályatervei. ÉPIP 37 (1914) 83-87.

Czigler Győző - Steindl Imre - Ybl Miklós: A kaposvári templomtervek bíráló bizottságának jelentése. ÉPIP 8 (1884) 39.

D.I.: Jubileumi templom. BH 42 (1914) február 22., 34-35.

Dercsényi Dávid: Kaposvár, Székesegyház. (Tájak Korok Múzeumok.) Budapest 1999.

Dór: A budapesti Ferenc-József jubileumi templom pályatervei. ÉPIP 37 (1914) 73-74.

Ezrey [Komor Marcell]: Ferenc József-templom. VL 35 (1914) 5-6.

Fülep Lajos: Magyar építészet. Nyugat 11 (1918) 8. http://epa.oszk. hu/00000/00022/00244/07341.htm (Utolsó megtekintés: 2018. 12. 30.)

Gábor Eszter: A lipótvárosi zsinagóga pályázata. Budapesti Negyed 5-6 (1997-98) 18-19. 5-47.

H. Gaal Adorján: A Budapest-lipótvárosi zsidó templom. MMÉEK 33 (1899) 125-130.

Haber Samu: A pesti hitközség templomtervei. Egyenlöség 13 (1899) 11., melléklet.

Hajnóczi Gábor: A nemzeti építészeti stílus kérdése az Akadémiapalota körüli vitában. In: Forradalom után - kiegyezés elött. Szerk.: Németh G. Béla. Gondolat, Budapest 1988. 195-214.

L[udwig] H[eves]-i: Wie soll mann den Leopoldstadter Tempel bauen? PL 46 (1899) április 8.

Hoss József: A kaposvári plébánia története. A veszprémi egyházmegye múltjából. 12. Egyházmegyei Nyomda, Veszprém 1948.

J.L.: „Köztereink” Buda és Vidéke 2 (1893) 173.

K.Á.: A budai új ref. templom fölavatása. VU 42 (1896) 218-219.

Kapitány-Horváth Zsuzsa: Aigner Sándor épitészete. Szakdolgozat, kézirat, 2011. 
Kelecsényi-Gyetvainé Balogh 2018 Kelecsényi Kristóf Zoltán - Gyetvainé Balogh Ágnes: Did a Steindl School exist?: The members of the design and technical management team of the Parliament in Budapest. Architektúra \& Urbanizmus 52 (2018) 1-2. 98-113.

Kemény 1991

Klebersberg 1932

Klein 2011

Komor 1899 a

Komor 1899 b

Krähling 2004

Krähling 2014

Krähling 2015

Krähling 2017

Magyar 1914

Majorossy 1930

Marótzy 2014

Meller 1900

Németh-Marótzy 2013

Németh-Marótzy 2018

Németh-Marótzy 2019

Objectivus 1899

Pap-Pruzsinszky 2000
Kemény Mária: Stílusválság vagy legitimitási válság? 2000. Irodalmi és társadalmi havi lap 3 (1991) 1. 57-61.

Klebersberg Kuno: A szegedi gondolat. MI 48 (1932) 1-2. 2-7.

Klein Rudolf: Zsinagógák Magyarországon 1782-1918. Terc, Budapest 2011.

Komor Marcell: Harminchárom terv. ÉPIP 23 (1899) 357-359.

Komor Marcell: A lipótvárosi templom tervei. Egyenlöség 13 (1899) 12. 4-6.

Krähling János: Építészettörténeti áttekintés. In: Evangélikus templomok a mai Magyarországon. Szerk.: Krähling János. (Veszendő templomaink III. Sorozatszerk.: Istvánfi Gyula.) Nemzeti Tankönyvkiadó, Budapest 2004. $15-25$.

Krähling János: Die Evangelische Kirche von Miklós Ybl in Kecskemét. Acta Historiae Artium Academiae Scientiarum Hungaricae 55 (2014) 1. 177-192.

Krähling János: The Protestant Church Architecture of East-Central Europe in the Seventeenth to Eighteenth Centuries - From Medieval Heritage to New Spatial Solutions: An Overview. In: Protestantischer Kirchenbau der Frühen Neuzeit in Europa: Grundlagen und neue Forschungskonzepte. Szerk.: Jan Harasimowicz. Schnell und Steiner, Regensburg 2015. 131146.

Krähling János: Pecz elmélete és a templomépítés gyakorlata: Utóhatása a magyarországi evangélikus templomépítészetében. Architectura Hungariae 16 (2017) 1. 21-31.

Magyar Vilmos: A Ferenc-József-jubileumi templom pályatervei. Kritika a kritikákról. ÉPIP 37 (1914) 95-96.

Majorossy Gyula: A Magyar Mérnök- és Építész-Egylet. In: Az 50 éves Vállalkozók lapja. Jubileumi album, 1879-1929. Biró Miklós Nyomdai Müintézet Rt., Budapest 1930. 58-60.

Marótzy Katalin: Ybl Miklós és az építészeti közélet - pályázatok a Magyar Mérnök- és Építész-Egyletben. Ars Hungarica 40 (2014) 4. 489496.

Meller Simon: A budapesti új zsidó templom. In: Évkönyv 11. Izraelita Magyar Irodalmi Társulat, Budapest 1900. 280-286.

Németh Nóra - Marótzy Katalin: Stíluskérdések a századfordulón - Két építészeti pályázat háttere. Épités - Épitészettudomány 41 (2013) 3-4. 253-270.

Németh Nóra - Marótzy Katalin: A bolgárajkú magyarok legnagyobb temploma. A vingai római katolikus templom építészeti pályázata. Dolgozatok az Erdélyi Múzeum Érem- és Régiségtárából 10 (2018).

Németh Nóra - Marótzy Katalin: Plan and Description. Architectural Histories 7 (2019) megjelenés alatt.

Objectivus: Der Leopoldstädter Tempelbau. PL 46 (1899) április 19., melléklet.

Pap Zsolt - Pruzsinszky József: Száz meg tizenöt év. A budapest-józsefvárosi Tisztviselötelep 115 éves története. I. kötet. 1886-1920. Széchenyista Öregdiákok Baráti Társasága, Budapest 2000. 
Paur 1899

Pálóczi 1899

Pecz 1888

Pecz 1920

rp 1914

Róka [é. n.]

Sándy 1895

Sándy 2005

Schulek 1885

Schulek 1891

Sisa 1998

Sisa 2013

Sommer 1899

Székely-Marótzy

Szinnyei 1899

Szőnyi 1932

Sztehló 1892

T. 1899

Takács 1992

Tandor 1895

Tar 1899

Velics 1894

Winkler 1992

x 1914
P[aur] G[éza]: Az ötödik kerületi új zsidó-templom pályázata. $V U 46$ (1899) 201-202.

Pálóczi Antal: Két tervpályázatról. ÉPIP 23 (1899) 12. 85-90.

Pecz Samu: A protestáns templomok építéséröl, kapcsolatban a debreceni kálvinista újtemplom részletes ismertetésével I-II. MMÉEK 18 (1888) 193-205, 241-251.

Pecz Samu: Pecz Samu müépitész, müegyetemi tanár életrajzi adatai és munkálkodása saját leírása szerint. Kézirat. Budapest 1920.

rp: Két új épület. Müvészet 13 (1914) 97-101.

Róka Enikő: A Szilágyi Dezső téri református templom. Protestáns templomok térképzése. http://www.academia.edu/ 18392509/ A_Szilágyi_Dezső_ téri_református_templom_Protestáns_templomok_térképzése (Utolsó megtekintés: $20 \overline{18}$. 12. 29.)

Sándy Gyula: A budai fazekastéri ev. ref. templom. ÉPIP 18 (1895) 240241, 250-251, 260-261.

Sándy Gyula: Hogyan lettem és hogyan voltam én templom-épitö, -tervezö és müvezetö épitész? (Lapis Angularis VI.) Magyar Építészeti Múzeum, Budapest 2005.

Schulek Frigyes: A református templom. ÉPIP 8 (1885) 1-2, 11-12, 21-22, 30 .

Schulek Frigyes: A budapest-erzsébetvárosi templom pályatervei. ÉPIP 15 (1891) 72.

Sisa József: Historizmus. In: Magyarország építészetének története. Szerk.: Sisa József, Dora Wiebenson. Vince Kiadó, Budapest 1998. 199-233.

A magyar müvészet a 19. században. Épitészet és iparmüvészet. Szerk.: Sisa József. Osiris, Budapest 2013.

Sommer, Josef: Pläne für den Bau eines neuen isr. Tempels in Budapest. $U B$ 3 (1899) 97.

Székely Márton - Marótzy Katalin: A pályázat mint jelenség a későhistorizáló építészet korában. Épités - Épitészettudomány 64 (2018) 1-2. 93-116. Szinnyei József: Magyar írók élete és munkái. VI. Hornyánszky, Budapest 1899.

Szőnyi Ottó: A szegedi fogadalmi templom. MI 48 (1932) 1-2. 26-32.

Sztehló Ottó: A szolnoki evang. ref. templom. ÉPIP 15 (1892) 317.

T.: Az izraelita hitközség új templomának tervpályázata. ÉSz 8 (1899) 7980 .

Takács Béla: A református templom. In: Református templomok Magyarországon. Szerk.: Déri Erzsébet. Hegyi \& Társa, Budapest 1992. XI-XXV. Tandor Ottó: Az ócsai templom restaurálása. MMÉEK 28 (1895) 1-9.

Tar Lörincz: Templomok. A Hét 10 (1899) 182.

Velics László: Egyházi művészetek tanulmányozásáról. KSz 7 (1894) 601. Winkler Gábor: Építészettörténeti áttekintés. In: Evangélikus templomok Magyarországon. Szerk.: Déri Erzsébet. Hegyi\& Társa, Budapest 1992. XXVII-XLV.

x: Tavaszi mükiállítások. KSz 18 (1914) 620-627. 


\title{
RÖVIDÍTÉSEK
}

BFL

BH

BTM Kiscell

EL

ÉPIP

ÉSz

$K S z$

$M E ́$

$M I$

MMÉEK

MMÉEHÉ

MNL OL

$M P$

OV

$\mathrm{PH}$

$P L$

$P N$

$P V$

$U B$

$V K$

$V L$

$V U$
Budapest Főváros Levéltára

Budapesti Hírlap

Budapesti Történeti Múzeum, Kiscelli Múzeum

Egyházmüvészeti Lap

Építési Ipar, Építő Ipar, Építő Ipar - Építő Művészet

Építészeti Szemle

Katolikus Szemle

Magyar Építőművészet

Magyar Iparmủvészet

Magyar Mérnök- és Építészegylet Közlönye

Magyar Mérnök és Építészegylet Heti Értesítője

Magyar Nemzeti Levéltár Országos Levéltára

Magyar Pályázatok

Ország-Világ

Pesti Hírlap

Pester Lloyd

Pesti Napló

Politisches Volksblatt

Ungarische Bauzeitung

Vállalkozók Közlönye

Vállalkozók Lapja

Vasárnapi Ujság

\section{ARCHITECTURE AND PRESS - FIVE REMARKABLE ARCHITECTURAL COMPETITIONS FOR SACRAL BUILDINGS IN THE ERA OF HUNGARIAN HISTORICISM}

\begin{abstract}
Summary
Examining the architectural competitions in the era of historicism their $19^{\text {th }}$ century representation is especially remarkable. These competitions are known from the architectural journals, rarely there are legacies to study in the archives. The presentation of the three dimensional architecture is as a matter of course two dimensional pictures and connecting texts in the print media. We demonstrate the relationship, and the alteration of this connection between texts and illustrations through five examples. Our case studies are all sacral buildings. (Roman Catholic church, Kaposvár, 1883-84; Calvinist church, Budapest, Fazekas / Szilágyi Dezső square 1891-92; Synagogue, Budapest, Leopold Town, 1898-99; Votive church, Szeged, 1903-04; Budapest, Franz Joseph I jubilee church 1913-14) The design and construction were particularly important for the communities. Thus their presence was not only significant in the architectural journals but also in the daily newspapers and in the so called family journals. It gives us the possibility to examine a wider context of the architectural plans.
\end{abstract}

Keywords: Historicism, Art Nouveau, architectural competition, architecture history

Open Access nyilatkozat: A cikk a Creative Commons Attribution 4.0 International License (https://creativecommons.org/licenses/by/4.0) feltételei szerint publikált Open Access közlemény, melynek szellemében a cikk bármilyen médiumban szabadon felhasználható, megosztható és újraközölhető, feltéve, hogy az eredeti szerző és a közlés helye, illetve a CC License linkje és az esetlegesen végrehajtott módosítások feltüntetésre kerülnek. (SID_1)

Beérkezett: 2019. január 4. Elfogadva: 2019. január 23.

Online First megjelenése: 2019. április 9. 